\title{
Water balance modelling in a semi-arid environment with limited in-situ data: remote sensing coupled with satellite gravimetry, Lake Manyara, East African Rift, Tanzania
}

D. Deus ${ }^{1,3}$, R. Gloaguen ${ }^{1}$, and P. Krause ${ }^{2}$

${ }^{1}$ Remote Sensing Group, Institut für Geologie, TU Bergakademie Freiberg, Bernhard-von-Cotta Strasse 2, 09596 Freiberg, Germany

${ }^{2}$ Department of Geoinformatics, Hydrology and Modelling, Friedrich-Schiller-University, Jena, Germany

${ }^{3}$ Department of Geomatics, School of Geospatial Sciences and Technology (SGST), Ardhi University, Dar es Salaam, Tanzania

Received: 9 September 2011 - Accepted: 18 September 2011

- Published: 26 September 2011

Correspondence to: D. Deus (dorothd@gmail.com)

Published by Copernicus Publications on behalf of the European Geosciences Union.

Water balance modelling in a semi-arid environment

D. Deus et al.

Title Page
Abstract

Conclusions

Tables

14

4

Back

Full Screen / Esc

Printer-friendly Version

Interactive Discussion
References

Figures

- I

Close

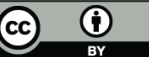




\section{Abstract}

Accurate and up to date information on the status and trends of water balance is needed to develop strategies for conservation and the sustainable management of water resources. The purpose of this research is to estimate water balance in a semi-arid 5 environment with limited in-situ data by using a remote sensing approach. We focus on the Lake Manyara catchment, located within the East African Rift of northern Tanzania. We use remote sensing and a semi-distributed hydrological model to study the spatial and temporal variability of water balance parameters within Manyara catchment. Satellite gravimetry GRACE data is used to verify the trend of the water balance result. The 10 results show high spatial and temporal variations and characteristics of a semi-arid climate with high evaporation and low rainfall. We observe that the Lake Manyara water balance and GRACE equivalent water depth show comparable trends a decrease after 2002 followed by a sharp increase in 2006-2007. Despite the small size of Lake Manyara, GRACE data are useful and show great potential for hydrological research on smaller un-gauged lakes and catchments in semi-arid environments. Our modelling confirms the importance of the 2006-2007 Indian Ocean Dipole fluctuation in replenishing the groundwater reservoirs of East Africa. The water balance information can be used for further analysis of lake variations in relation to soil erosion, climate and land cover/land use change as well as different lake management and conservation scenarios. We demonstrate that water balance modelling can be performed accurately using remote sensing data even in complex climatic settings.

\section{Introduction}

Quantifying the hydrological budget in arid and semi-arid regions is important as scarcity of water and climatic variability lead to conflicts regarding water use (Troch, 2000; Güntner et al., 2004). Water resources in semi-arid regions have received slight consideration principally due to complexity and a lack of in-situ data (Andersen, 2008).
HESSD

8, 8737-8792, 2011

\section{Water balance modelling in a semi-arid environment}

D. Deus et al.

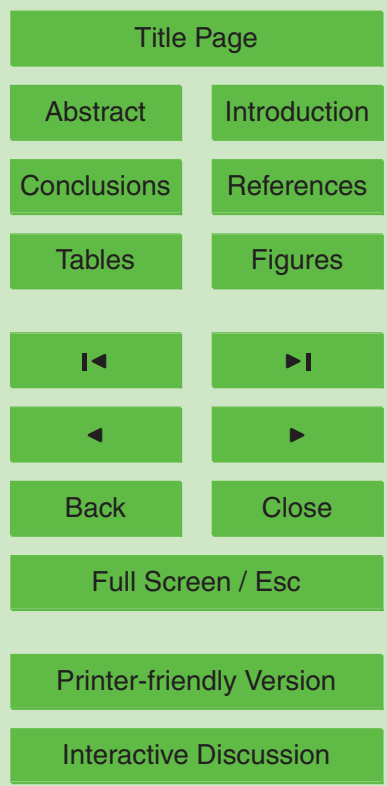


However, the advent of satellite derived hydrological measurements and increased stress on water resources has triggered more interest in such research (Troch, 2000; Andersen, 2008). The hydrological behaviour of a semi-arid catchment basin as expressed by both direct and base flow is affected by a number of factors. These in5 clude the spatial variation of topography, soils, vegetation, land use, river topography, structural geology and the spatial temporal variation of climate (Güntner and Bronstert, 2004). In many semi-arid regions of the world surface water provides the major source of water (Güntner et al., 2004). In this study we investigate a simulation of water balance for a lake and its catchment basin, located in a semi-arid hydrological setting.

10 Lakes are dynamic entities and sensitive to climatic and environmental change. In the East African Rift the topography of the rift escarpments and volcanic highlands plays an important role in controlling local climate and thus the lake basins (Yanda and Madulu, 2005; Goerner et al., 2008; Böhme et al., 2006). Lakes are sensitive indicators of changes in the balance between precipitation, water flow into the lake, water loss 15 from the lake through evaporation, seepage and drainage (Simonsson, 2001). Lake level fluctuations vary with the water balance of the lake and its catchment and may in certain cases reflect changes in rainfall, evaporation and shallow groundwater resources (Awange et al., 2008; Swenson and Wahr, 2009; Becker et al., 2010). Lake Manyara is an example of a lake that has fluctuated considerably in depth and area over recent years (Simonsson, 2001). The Lake Manyara water balance is unknown as the largest part of its catchment is un-gauged and the inflow is unknown.

In this study, we use remote sensing (RS) observations to approximate the spatial and temporal variation of hydrological parameters over Lake Manyara and its catchment which are used as inputs for the J2000g model (Krause and Hanisch, 2009).

25 Some ground measurement and Gravity Recovery and Climate Experiment (GRACE) satellite gravimetry equivalent water thickness data (Swenson and Wahr, 2006) has been employed to verify the trend of the Lake Manyara water balance. Over recent years several studies have applied remote sensing observations and GRACE to study the hydrological cycles of lakes, rivers and associated basins in the East African Rift
HESSD

8, 8737-8792, 2011

\section{Water balance \\ modelling in a semi-arid environment}

D. Deus et al.

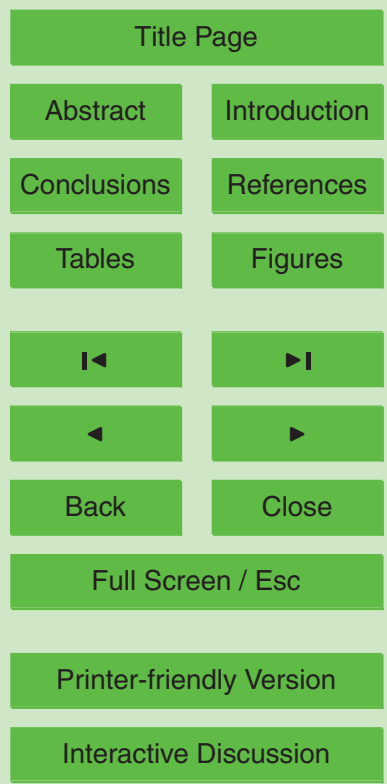


and elsewhere (Milzow et al., 2011; Khan et al., 2011; Becker et al., 2010; Hwang et al., 2011; Swenson and Wahr, 2009). Changes in a basin's water budget are directly linked to local gravity variations (Awange et al., 2008). GRACE satellite gravity data can provide an estimate of terrestrial stored ground water and has the potential to deliver 5 a better understanding of the properties and significance of groundwater (Hildebrand, 2005). The purpose of this work is to utilize remote sensing and GRACE data with the following objectives: (a) to quantify the water balance components in the lake and the overall basin; and (b) to test the applicability of the J2000g hydrological model in a data poor semi-arid lake basin, and (c) test the utility of GRACE satellite gravimetry 10 total water storage (TWS) data on a smaller un-gauged lake catchment basins and minor lakes that are not included in the global satellite altimetry mission network.

\section{Description of the study area}

\subsection{Setting}

Lake Manyara is the southernmost lake within the eastern arm of the Gregory Rift Val15 Quaternary rifting and volcanism has exerted a strong control on surface morphology (Casey et al., 2006; Keranen et al., 2004; Kurz et al., 2007). The lake is shallow and saline, $126 \mathrm{~km}$ west of Arusha, Northern Tanzania $\left(3^{\circ} 25^{\prime}-3^{\circ} 48^{\prime} \mathrm{S}, 35^{\circ} 44^{\prime}-35^{\circ} 53^{\prime} \mathrm{E}\right.$, 960 m a.s.l., Fig. 1).

The lake varies from $410 \mathrm{~km}^{2}$ to $480 \mathrm{~km}^{2}$ in depth and has at times dried up completely (Yanda and Madulu, 2005). The present Lake Manyara is the residual portion of a much larger palaeolake that was $300 \mathrm{~m}$ deeper. Somi (1993) reconstructed Lake Manyara palaeo-shorelines based on evidence from shore marks, algal stromatolites and beach deposits. A May/June 2010 bathymetry survey indicates the average water 25 depth is just $1.18 \mathrm{~m}$. The Lake Manyara catchment area covers about $18763 \mathrm{~km}^{2}$ and lies between $885 \mathrm{~m}$ and $3618 \mathrm{~m}$ a.s.I. It is a closed basin with no outlet (Yanda and
HESSD

8, 8737-8792, 2011

\section{Water balance modelling in a semi-arid environment}

D. Deus et al.

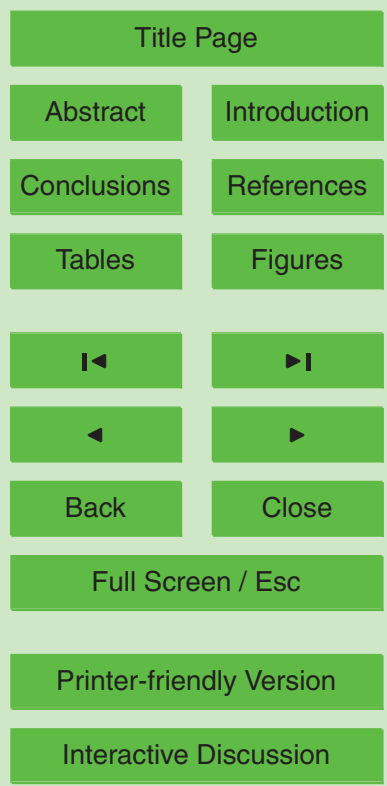


Madulu, 2005). The western side of the lake is flanked by a deep escarpment, while in the east an undulating plain with isolated volcanic cones gives way to a peneplain. Several springs and streams, both perennial and seasonal, drain into the Lake Manyara (Yanda and Madulu, 2005).

The climate of East Africa is principally influenced by the seasonal shift of the Intertropical Convergence Zone (ITCZ) (Kaspar et al., 2008; Khan et al., 2011). The Lake Manyara basin lies within a semi-arid to semi-humid tropical climate zone characterized by high evaporation rate and low rainfall. In semi-arid regions rainfall events are of short duration and high intensity and often characterized by a large degree of spatial heterogeneity (Wheater et al., 2007; Pilgrim et al., 1988; Andersen, 2008). Lake Manyara has highly seasonal and annually variable rainfall that totals approximately $600 \mathrm{~mm} \mathrm{yr}^{-1}$ (Fig. 2). In general, the rainy season lasts from November to May with a short and a long rainy season. The short rains (Vuli) occur between November and January. These 15 rains can be interrupted by a short dry season in January and February. The long rains (Masika) occur between February and May. The dry season from June to October is consistent and lengthens when the short rains fail (Copeland, 2009; Prins and Loth, 1988).

Atmospheric temperatures at the lake range from $14^{\circ} \mathrm{C}$ to $30^{\circ} \mathrm{C}$, with peaks from 20 December to February (Fig. 3). Figure 3 shows the relations of both mean temperature variability and diurnal variability throughout the two distinct seasons over the study period (2001-2009).

\section{HESSD}

8, 8737-8792, 2011

\section{Water balance modelling in a semi-arid environment}

D. Deus et al.

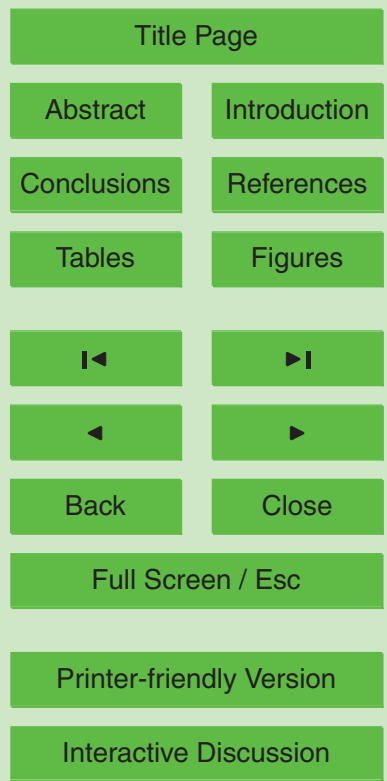




\section{Data and parameters}

\subsection{Data sets}

HESSD

In-situ data availability for Lake Manyara and its surroundings for hydrological modelling is a great challenge. Limited information is available concerning the Lake and

5 its catchment in general as the lake is un-gauged and the basin poorly gauged. The hydrological observation network is very sparse and the number of gauging stations has been decreasing since the 1990s. Satellite-based techniques provide us with potential continuous hydrological data required by hydrological models when we have a limited network to make in-situ measurements for model calibration and validation. In 10 this study we have applied different types of data based on ground and remote sensing measurements as J2000g hydrological model inputs. The data sets include rainfall, temperature, humidity, wind speed, sunshine duration, runoff, evaporation, land use/land cover, soil, geology and topography (elevation, aspect and slope).

\subsubsection{Remote sensing observation}

15 Rainfall

Rainfall is the most essential component in water balance estimations. It is a key forcing variable in hydrological models and hence spatially and temporally correct rainfall measurement is critical in hydrologic modelling processes and the management of water resources, especially in semi-arid regions (Sorooshian et al., 2005; Gebremichael et al., 2006; Khan et al., 2011). We utilize both in-situ precipitation and Tropical Rainfall Measuring Mission (TRMM) amalgamated rainfall product (3B43-V6) with a spatial resolution of $0.25^{\circ} \times 0.25^{\circ}$ to characterize the main inflow parameter in the Manyara basin (Kummerow et al., 1998). TRMM 3B43 product is created by combining TRMM data with SSM/I, VIS/IR and rain gauge data (Huffman et al., 2007). We acquired the

8, 8737-8792, 2011

\section{Water balance modelling in a semi-arid environment}

D. Deus et al.

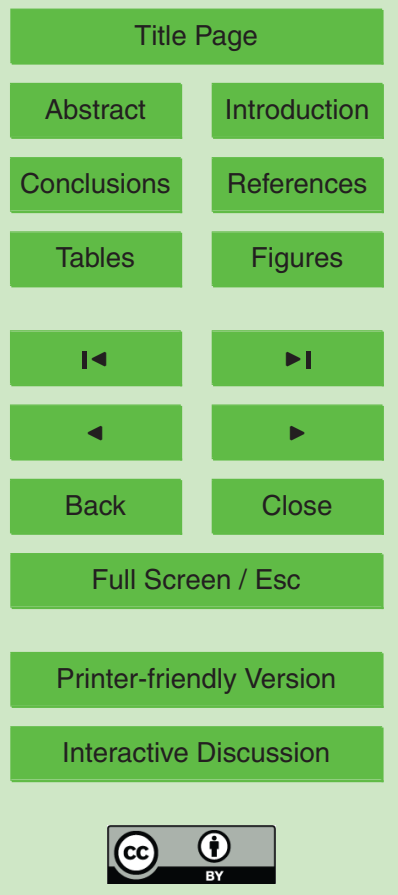


the GES-DISC interactive online visualization and analysis infrastructure (Giovanni) as part of NASA's Goddard Earth Sciences (GES) Data and Information Services Centre (DISC) from http://disc2.nascom.nasa.gov/Giovanni/tovas/. TRMM data are suitably accurate even for mountainous areas (Andermann et al., 2011). We checked the suit5 ability of the TRMM data in the Manyara basin with a comparison of TRMM 3B43 V6 accumulated precipitation product with in-situ data. TRMM displayed a Pearson's correlation coefficient $(R)$ of 0.82 (Fig. 4).

The Global Precipitation Climatology Project (GPCP) precipitation product for the field area gives a Pearson's correlation coefficient of 0.84 (Fig. 4). Both TRMM 3B43 V6 10 and GPCP rainfall products underestimate precipitation in the catchment. GPCP rainfall product amalgamates microwave and infrared satellite observations as well as rain gauge data. GPCP provides a record of almost 30 years of global monthly precipitation and daily rainfall starting in 1979 (Huffman et al., 1995; Adler et al., 2003; Prigent, 2010). The data used are derived from the GPCP database http: 15 //disc2.nascom.nasa.gov/Giovanni/tovas/ground.GPCC.shtml.

\section{Temperature}

We used MODIS/Terra (Earth Observing System (EOS) AM-1 platform) day and night time MOD11C1 V4 and V4.1 land surface temperature (LST) product at a spatial resolution of $0.05^{\circ} \times 0.05^{\circ}$ (Wan, 2008). MOD11C1 V4 product is available from March 2000 20 to the end of 2006 and MOD11C1 V4.1 dataset covers the time period starting from the end of 2006 to 2010 . MOD11C1 daily global LST product estimates are derived by re-projection and averaging of the values in the daily MODIS LST product (MOD11B1) at $6 \mathrm{~km}$ equal area climate modelling grids in the sinusoidal projection. MOD11B1 LST product is derived with the results produced by the day/night LST algorithm (Wan and (bands 20, 22, 23, 29, and 31-33) only in clear-sky conditions so that LST is not mixed with cloud-top temperature. LST is defined by the radiation emitted by the land surface observed by MODIS at instant viewing angles (Wan et al., 2004). The MODIS/Terra

\section{HESSD}

8, 8737-8792, 2011

\section{Water balance modelling in a semi-arid environment}

D. Deus et al.

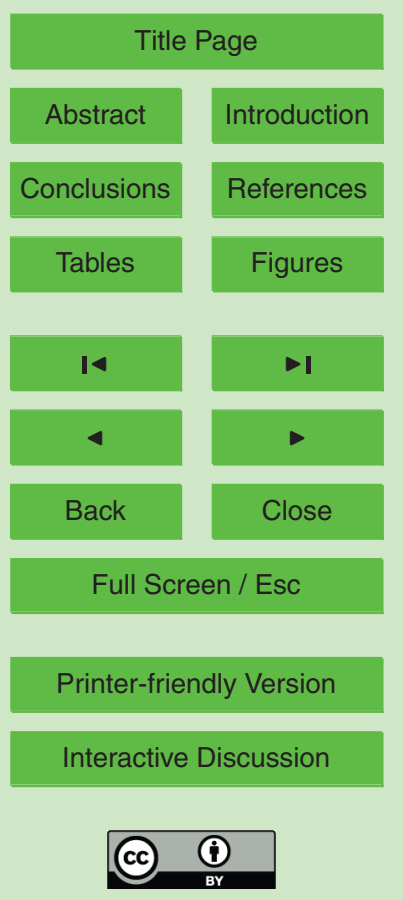


scans in 36 spectral bands, with bands $1-19$ and 26 in the visible and near infrared (IR) range and the remaining bands in the thermal IR (TIR) from 3 to $15 \mu \mathrm{m}$ (Wan et al., 2002; Barnes et al., 1998; Guenther et al., 1998).

LST is one of the key parameters in the physics of land surface processes on regional 5 and global scales. It combines the results of all surface atmosphere interactions and energy fluxes between the atmosphere and the ground (Wan et al., 2004). Wan et al. (2004) validated the accuracy of daily MODIS LST products in more than 20 clearsky cases with in-situ measurement. They found that MODIS LST accuracy is better than $1^{\circ} \mathrm{C}$ in the range from $-10^{\circ}$ to $50^{\circ} \mathrm{C}$. We compared a combination of MOD11C1 V4 10 and V4.1 LST product on the study area using a dataset covering 2003-2009 (Fig. 5). We found that the monthly daytime LST closely fits in-situ temperature data with a coefficient of determination $\left(R^{2}\right)$ of 0.52 . The monthly night-time LST product fits in the area of interest with a lower coefficient of determination $\left(R^{2}=0.32\right)$ compared to the day temperature product. The averaged day and night time MODIS LST shows 15 the coefficient of determination, $R^{2}$ of 0.44 . On examination of the linear fitting trend (Fig. 5) it can be observed that MODIS day temperatures overestimate and MODIS night temperature underestimate the in-situ temperature values.

\section{Land cover}

Variation in land cover affects soil properties and infiltration rates, and by extension

soil erosion processes and the hydrological cycle of the basin. We used Land cover types extracted from MODIS Land Cover Product (MOD12Q1) based on the International Geosphere-Biosphere Programme (IGBP) classification scheme (Loveland and Belward, 1997). MOD12Q1 global land cover product correction 5 includes a set of internally consistent layers depicting different land cover classifications at a spatial reso-

lution of $500 \mathrm{~m}$. In Manyara we identified thirteen land cover classes: Water, evergreen broadleaf forest, deciduous broadleaf forest, mixed forests, closed shrub land, open shrub land, woody savannahs, savannahs, grasslands, permanent wetlands, urban and built-up, cropland-natural vegetation mosaic, and barren or sparsely vegetated.

8744

\section{HESSD}

8, 8737-8792, 2011

\section{Water balance modelling in a semi-arid environment}

D. Deus et al.

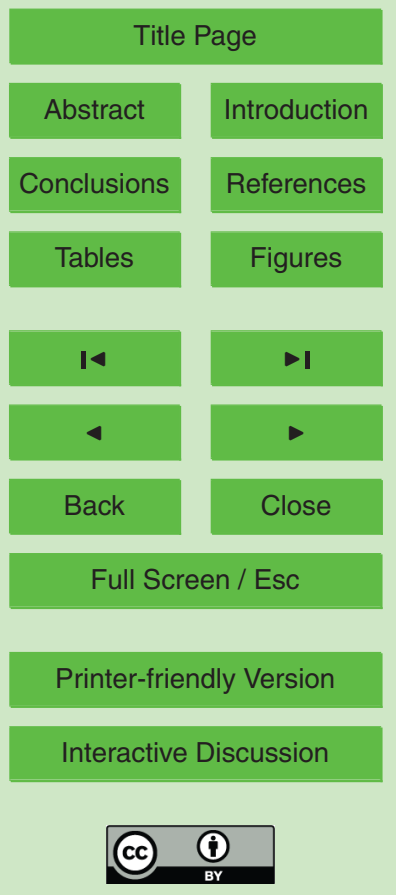


The data was downloaded from NASA's Earth Observing System (EOS) data archive through https://wist.echo.nasa.gov/wist-bin/api/ims.cgi/.

\section{Topography (elevation, slope and aspect)}

Topography has a great impact on the manner by which the hydrologic cycle impacts 5 the earth surface. Surface runoff causes soil erosion. When water infiltrates the soil it can accumulate into base flow that may eventually join the river system. The removal of rainfall into via evaporation increases at lower elevations. We used SRTM (Shuttle Radar Topography Mission) Digital Elevation Model (DEM) for the topography with $90 \mathrm{~m}$ resolution (Jarvis et al., 2008). The data was downloaded from http://srtm.csi.cgiar.org.

\section{GRACE equivalent water thickness}

The Gravity Recovery and Climate Experiment (GRACE) satellite project is administered by the US National Aeronautics and Space Administration (NASA) and its German Aerospace Centre (DLR). The mission was launched in March 2002 to provide spatial-temporal variations of Earth's gravity field over various time scales (month to decadal). Changes of gravity are mainly due to the relocation of water over the earth. Gravity data can be used to derive global estimates of total water storage (TWS) with a spatial resolution of $100 \mathrm{~km}$ and above, with higher accuracies over larger spatial scales (Swenson and Wahr, 2009; Wahr et al., 2004).

Monthly gravity field solutions are computed at the University of Texas at Austin Center for Space Research (CSR), the German Research Centre for Geosciences Potsdam (GFZ), the Jet Propulsion Laboratory (JPL), the Groupe de recherche de geodesie spatiale (GRGS), and the Delft Institute of Earth Observation and Space Systems (DEOS) as well as at Delft University of Technology, among others. In this study we used the most recent land mass grid of GRACE data release (RL04) from CSR (Swenson and Wahr, 2006). The data are available as monthly $1^{\circ} \times 1^{\circ}$ grids TWS over land, expressed in units of equivalent water thickness. We used a dataset of
HESSD

8, 8737-8792, 2011

\section{Water balance modelling in a semi-arid environment}

D. Deus et al.

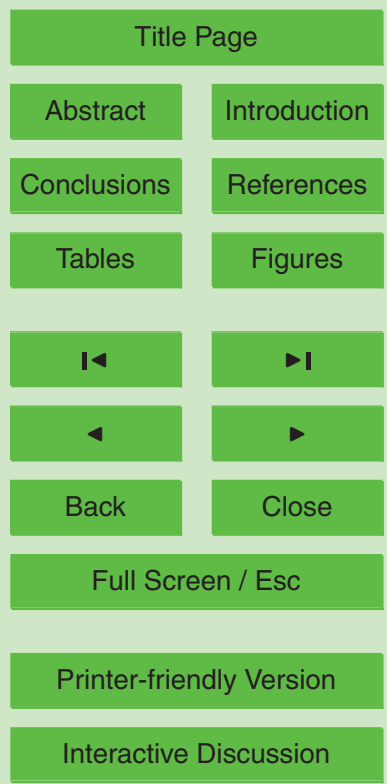


89 months covering the period from August 2002 to December 2009. One month is missing: June 2003. This dataset is accessible from http://grace.jpl.nasa.gov./data/ gracemonthlymassgridsland/.

\section{Altimetric lake height}

5 The principal focus of a satellite altimeter is to map oceanic sea surface heights. However, over recent decades they have also been used to detect water level changes in lakes and inland seas (Crétaux and Birkett, 2006; Birkett et al., 1999). We investigate lake levels for two lakes in the vicinity of Lake Manyara-Lake Victoria and Lake Rukwa. The data is provided by LEGOS/GOHS (Laboratoire d'Etudes en Geodesie et Oceanographie Spatiales, Equipe Geodesie, Oceanographie, et Hydrologie Spatiales), part of the French space agency CNES, from http://www.legos.obs-mip.fr/soa/ hydrologie/hydroweb/. The LEGOS/GOHS time series are based on data from a combination of satellites: Topex/Poseidon, ERS-2, GFO, Jason-1, and ENVISAT. We use altimetric height levels from January 2002 to December 2009.

\subsubsection{In-situ datasets}

We use different types of ground measurement and geographical information system (GIS) data to extract model parameters, simulation and validation of remote sensing observations and results. The meteorological dataset (Fig. 6) includes monthly records of rainfall, temperature (maximum, minimum and mean), evaporation, relative humidity, sunshine duration, wind speed and discharge data. There are about five rain gauges within the catchment, two discharge stations and one meteorological station around Lake Manyara that provide reliable data.

We use two GIS maps used to extract soil and hydrogeological parameters. Several different soil groups are found in the field area: Vertisols, Phaeozems, Leptosols, silty-clay texture and are moderately-to well-drained. Leptosols consist of clay-loam to

HESSD

8, 8737-8792, 2011

\section{Water balance modelling in a semi-arid environment}

D. Deus et al.

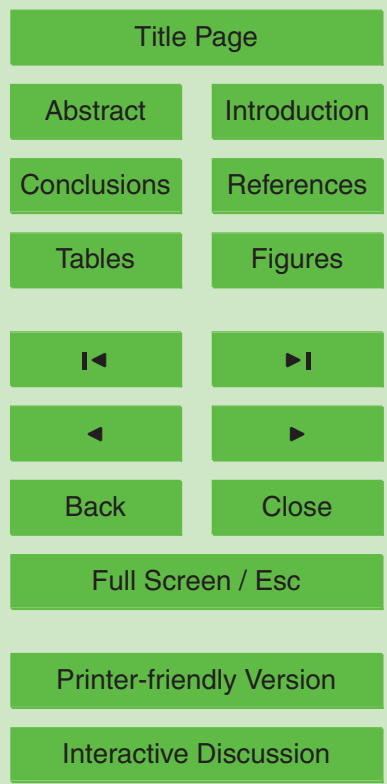


clay, are drained moderately deep, and have a lower water holding capacity than fluvisols and luvisols. Nitisols have a silty clay to clay texture and are well-drained. Vertisols are clay soils with a poor drainage capability. Soils information is taken from the harmonized world soil database (HWSD) (FAO et al., 2009). The database was accessed 5 from http://www.iiasa.ac.at/Research/LUC/External-World-soil-database/. Lake Manyara lies within on a plateau of sedimentary, metamorphic and volcanic rocks. This geological information was digitized from a 1:2000 000 geological map of Tanzania (2004).

\subsection{Model input parameters}

The J2000g model requires two types of input values: temporally varying and constant.

10 The time series climate data is the first input and this includes absolute and relative humidity, sunshine duration, maximum, mean and minimum temperature, wind speed, precipitation and observed runoff. The second input is what we refer to as parameters. These are Hydrological Response Unit (HRU) grid-based parameters related to: (1) land use/land cover such as albedo, stomata conductance $\left(R_{\mathrm{sco}}\right)$, maximum plant 15 height $\left(H_{\max }\right)$, leaf area index ( $\left.\mathrm{LAI}\right)$, maximum root depth $\left(R_{\mathrm{Dmax}}\right)$ and minimum surface resistance for water-saturated soil (Table 1), (2) soil thickness and useable field capacity per decimetre of profile depth, (3) the maximum possible percolation rate (ground water recharge rate) per time interval in $\mathrm{mm}$ per time unit, (4) mean elevation, slope and aspect. Albedo is the ratio of reflected to incident radiation from the sun. Accurate parameterisation of surface albedo is important in modelling energy balances of a given land cover (Iqbal, 1983). We adopted albedo values from Strugnell et al. (2001). Stomata conductance is a fundamental factor in many ecological models and plays a significant role in the plant-atmosphere water exchange (Chen et al., 1999). We used stomata conductance values based on Lambin (1999) and Yucel (2006). In hydrology, vegetation, which in turn may be used to calculate potential evapotranspiration. We adopted typical values for the maximum plant height of different species from Breuer et al. (2003). LAl is used to calculate the surface resistance of the soil cover. The rooting

\section{HESSD}

8, 8737-8792, 2011

\section{Water balance modelling in a semi-arid environment}

D. Deus et al.

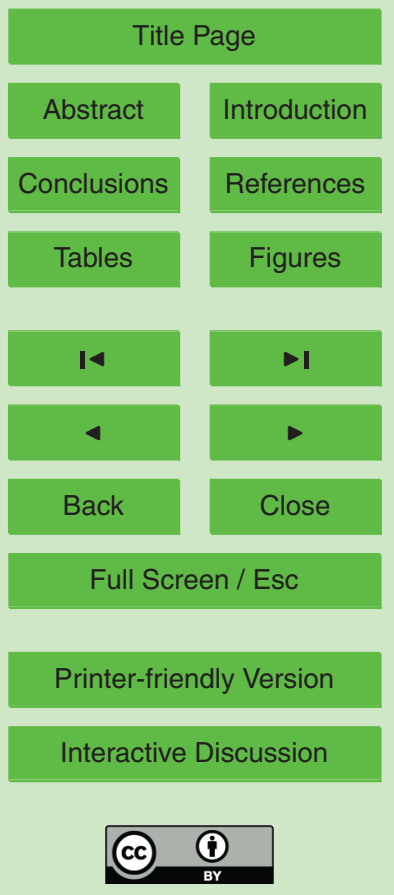


depth of plants determines the maximum depth of water and nutrient uptake from the soil profile. We acquired LAI values from Ge et al. (2007) and Breuer et al. (2003). Maximum root depth $R_{\text {Dmax }}$ depends largely on soil texture, compaction, underlying bedrock, clefts, and further physical and chemical properties of the soil (Breuer et al.,

\section{Approaches}

\subsection{Water balance}

In this study the spatially distributed conceptual water balance model has been selected to simulate and quantify the main water budget parameters for Lake Manyara and its surroundings (Krause and Hanisch, 2009). The model is implemented in the Jena Adaptable Modelling System (JAMS) framework (Kralisch and Krause, 2006). A water balance model is a mathematical expression that describes the flow of water in and out of a hydrological system such as a drainage basin or lake. It is based on the mass and energy conservation principle within an identified domain and specified time period. Dingman (2002) explained that water balance is the change in water quantity for a specific control volume over time. The catchment water balance (Thornthwaite, 1948; Willmott et al., 1985) is expressed as:

$\frac{\mathrm{d} S}{\mathrm{~d} t}=$ Inflow - Outflow

$\frac{\mathrm{d} S}{\mathrm{~d} t}=P-\mathrm{ET}-Q$

20 where $\frac{d S}{d t}$ is the change in storage for a certain interval of time, $P$ is precipitation, $Q$ is runoff and ET is evapotranspiration. For long periods, the change in storage can be considered negligible (Eq. 3), such that $Q$ is articulated as a remainder of $P$ and ET (Eq. 4):

HESSD

8, 8737-8792, 2011

Water balance modelling in a semi-arid environment

D. Deus et al.

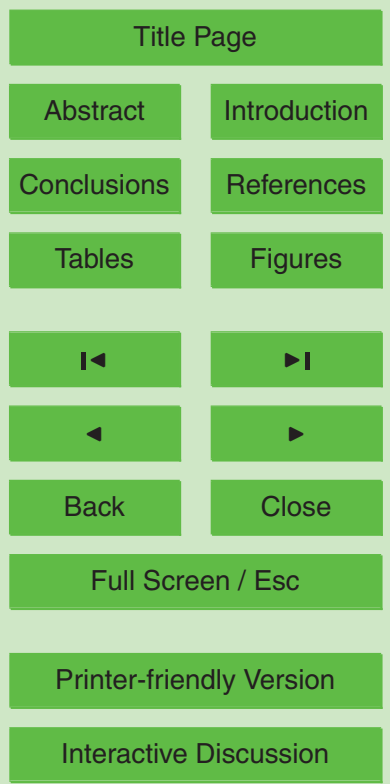


However, for the lake catchment water balance, estimations of both aquatic and terrestrial processes must be considered. Given the values for the amount of precipitation,

5 lake evaporation $(E)$ and evapotranspiration while assuming a homogeneous substrate throughout the lake's catchment, the water balance of the entire catchment can be expressed as a sum of the water balance from the terrestrial part of the lake catchment (LT) and that of the lake surface area (LA) (Cardille et al., 2004). With an averaged condition over time the change in storage becomes negligible such that Eq. (4) holds.

10 In groundwater systems, outputs from a catchment occur through underground water flow from the lake $(U)$ or base flow (subsurface runoff) and overland flow $(Q)$ or surface runoff and balance the inputs to the catchment as in Eq. (5):

$U+Q=\mathrm{LT}(P-\mathrm{ET})+\mathrm{LA}(P-E)$.

The input and output components of the water balance of a lake depend not only

on the physical dimension of the water body, but also on the climatic, hydrological and geological factors affecting the water body and its surrounding areas (Awulachew, 2006). For lakes surrounded by a small catchment basin area the water balance is more strongly driven by evaporation than by evapotranspiration. On the other hand lakes with a large catchment basin area relative to the lake surface area reflect a water balance more closely linked to the value of precipitation minus evapotranspiration such that the lake water balance is driven by a weighted combination of $P-$ ET and $P-E$ (Cardille et al., 2004). For Lake Manyara, by neglecting the change in storage over a long period we identify the principal component of the water balance to be precipitation on the lake, inflow $\left(Q_{\text {in }}\right)$ to the lake and lake evaporation. Thus the lake water balance (WB) can be expressed as:

$\mathrm{WB}=P-E+Q_{\text {in }}$.

\section{Water balance modelling in a semi-arid environment}

D. Deus et al.

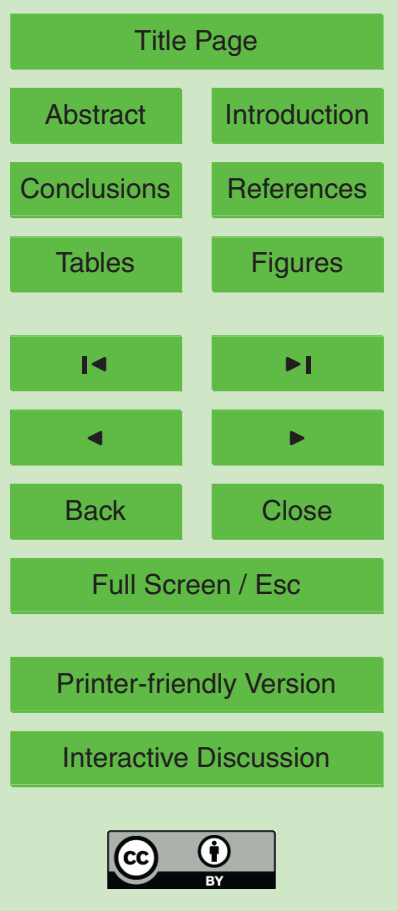


$Q_{\text {in }}$ can be further decomposed in to

$Q_{\text {in }}=Q_{\text {direct }}+Q_{\text {baseflow }}$

where $Q_{\text {direct }}$ and $Q_{\text {baseflow }}$ represent surface and subsurface runoff respectively. Each term describes the spatial average taken over the entire lake area.

\subsection{Evapotranspiration}

Evapotranspiration (ET) is the largest component of water balance computations for a semi-arid climate (Wilcox et al., 2003). It is a crucial factor between land, water surface and the atmosphere. In semi-arid regions evaporation from bare soil assumes a greater importance relative to transpiration from plants, due to the larger area of bare soil and the frequency of small rainfall events (Pilgrim et al., 1988; Andersen, 2008). A broad analysis of the ET processes and determination of spatial and temporal ET and $P$ estimates are required to obtain reliable estimates of water balance, as the difference between $P$ and ET defines what is left for recharge and runoff. We calculate both actual and potential using the J2000g model based on Penman-Monteith (Allen et al., 1998) (Eq. 8). The Penman-Monteith equation refines weather-based potential evapotranspiration (PET) estimates for vegetated land areas and it is widely regarded as one of the most accurate models, in terms of estimates based on physical background. The model requires daily mean temperature, wind speed, relative humidity, and solar radiation to predict net $\mathrm{ET}$. Actual evapotranspiration (AET) is regarded as the amount of water that is evaporated until no more water exists in the soil water module implying that the PET cannot be reached.

To compute evaporation from the lake we use the approach of Penman (1948). Evaporation from lakes is a key constituent of the water balance; hence its accurate determination is essential for a reasonable estimate of the water balance. The Penman method has been found suitable for evaporation estimation under any climatic conditions and for a time scale of up to one month (Jensen et al., 1990). The Penman

\section{Water balance modelling in a semi-arid environment}

D. Deus et al.

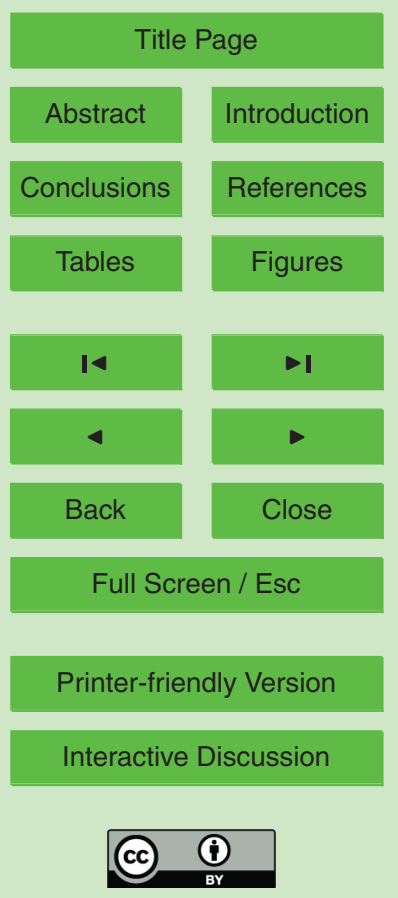


approach combines the fact that evaporation is a diffusive process and that energy can be expressed in terms of mass (Kebede et al., 2006).

PET $=\frac{1}{L_{\mathrm{d}}} \times \frac{S \times\left(R_{\mathrm{n}}-G\right)+\rho \times C_{\mathrm{p}} \times \frac{\text { es }- \text { ea }}{r_{\mathrm{a}}}}{S+\gamma \times\left(1+\frac{r_{\mathrm{s}}}{r_{\mathrm{a}}}\right)}\left[\frac{\mathrm{mm}}{\mathrm{day}}\right]$

where $L_{\mathrm{d}}$ : latent heat of evaporation $\left[\mathrm{MJ} \mathrm{kg}^{-1}\right.$ ], $S$ : slope of the vapor pressure curve $5 \quad\left[\mathrm{kP}_{\mathrm{a}} \mathrm{K}^{-1}\right], R_{\mathrm{n}}$ : net radiation $\left[\mathrm{MJ} \mathrm{m} \mathrm{m}^{-2} \mathrm{~d}^{-1}\right], G$ : soil heat flux $\left[\mathrm{MJ} \mathrm{m}^{-2} \mathrm{~d}^{-1}\right], \rho$ : density of the air $\left[\mathrm{kg} \mathrm{m}^{-3}\right], C_{\mathrm{p}}$ : specific heat capacity of the air $\left(=1.031 \times 10^{-3} \mathrm{MJ} \mathrm{kg}^{-1} \mathrm{~K}^{-1}\right]$, es: saturation vapor pressure of the air $\left[\mathrm{kP}_{\mathrm{a}}\right]$, ea : actual vapor pressure of the air $\left[\mathrm{kP}_{\mathrm{a}}\right], \gamma$ : psychrometer constant $\left[\mathrm{kP}_{\mathrm{a}} \mathrm{K}^{-1}\right], r_{\mathrm{a}}$ : aerodynamic resistance of the land cover $\left[\mathrm{s} \mathrm{m}^{-1}\right]$, $r_{\mathrm{s}}$ : surface resistance of the land cover $\left[\mathrm{s} \mathrm{m}^{-1}\right]$.

\section{Model setup, calibration and validation}

\subsection{Model setup}

The performance of a model in terms of prediction depends on the setup and parameterization. The J2000g water balance model setup involves catchment and parameter discretization into a spatially distributed format, selection of initial calibration parameter values and time setup. The model is simplified to temporally aggregate and spatially distribute the hydrological targets to be calculated. The representation and calculation of the hydrological processes in the model is carried out in one-dimension for any number of points in space. We applied grid cell as a distribution concept throughout the model. The catchment basin was discretised into grid cells, each with a spatial resolution of $1 \mathrm{~km}$. All physical parameter layers were translated to same extent exactly in terms of projection and re-sampled to pixels of $1 \mathrm{~km}$ by $1 \mathrm{~km}$ so as to overlay the parameters belonging to the same grid entity correctly. This implies that inside one
HESSD

8, 8737-8792, 2011

Water balance modelling in a semi-arid environment

D. Deus et al.

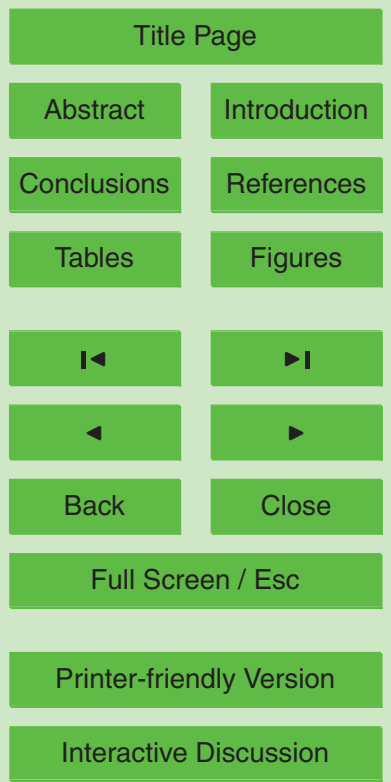


modelling grid there is one value parameter for each land cover type, soil, permeability, slope, aspect, and elevation (Fig. 7).

We performed the temporal discretization of the modelling step on a monthly basis. During modelling we computed the following processes for each time step: the region5 alization of climate data to the modelling units, calculation of global and net radiation as inputs for the evaporation calculation, calculation of land cover specific potential evaporation according to the Penman-Monteith equation (Eq. 8), soil water balance, groundwater recharge and discharge delay.

\subsection{Model calibration and validation}

10 The reliability of model predictions depends on how well the model structure is defined and how well the model is parameterized (Liu et al., 2005). Estimation of model parameters is normally sensitive and challenging due to uncertainties associated with the determination of parameter values that cannot be obtained straight from the field. Due to the lack of long term discharge observations and lake volume data we did not calibrate the model over the study period (2001-2009). We adopted parameters obtained from a model that was calibrated using a two month daily observed runoff dataset that was acquired in April-June 1980 (Fig. 8a,b). We selected the best calibration parameters for this model based on the Nash-Sutcliffe model efficiency coefficient of 0.60 , coefficient of determination, $R^{2}=0.67$, absolute volume error(AVE) of $12.5 \%$, root mean square error of 3.5 and a relative volume error (PBIAS) of -2.915 .

We evaluated the goodness-of-fit of the observed and simulated data sets based on a visual comparison and Pearson's product moment correlation coefficient (Eq. 9) to support the judgement. Having a series of $n, x$ observations and $n, y$ model values at time $i$, the Pearson correlation coefficient was used to measure their linear relationship. 25

The correlation, $R$ is +1 in the case of a perfect increasing linear relationship, and -1 in case of a decreasing linear relationship, and the values in between indicate the degree of linear relationship between observed and simulated dataset. A correlation coefficient of 0 means the there is no linear relationship between the variables. The coefficient of

8, 8737-8792, 2011

\section{Water balance modelling in a semi-arid environment}

D. Deus et al.

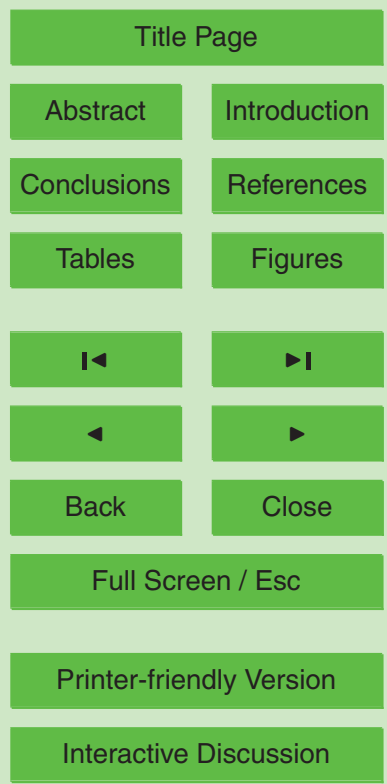


determination, $R^{2}$, describes how much of the variance between the two variables is described by the linear fit.

$$
R=\frac{\sum_{i=1}^{n}\left(x_{i}-\bar{x}\right) \cdot\left(y_{i}-\bar{y}\right)}{\sqrt{\sum_{i=1}^{n}\left(x_{i}-\bar{x}\right)^{2} \cdot \sum_{i=1}^{n}\left(y_{i}-\bar{y}\right)^{2}}} .
$$

To assess the model prediction efficiency we applied the Nash-Sutcliffe coefficient 5 (Nash and Sutcliffe, 1970). The Nash-Sutcliffe model efficiency coefficient (NS) is usually employed to measure the predictive power of hydrological models. It can also be used to quantitatively describe the accuracy of model outputs. It is computed as (Eq. 10):

$\mathrm{NS}=1-\frac{\sum_{i=1}^{n}\left(x_{\mathrm{obs}, i}-X_{\text {model }}\right)^{2}}{\sqrt{\sum_{i=1}^{n}\left(X_{\mathrm{obs}, i}-X_{\mathrm{obs}}\right)^{2}}}$

10 where $X_{\text {obs }}$ is observed values and $X_{\text {model }}$ is modelled values at time $i$. Nash-Sutcliffe efficiencies can range from $-\infty$ to 1 . A value of 1 corresponds to a perfect match between modelled and observed values while 0 shows that the model predictions are as accurate as the mean of the observed dat. An efficiency of less than zero $(-\infty<N S<0)$ occurs when the observed mean is a better predictor than the model. The closer the model efficiency is to 1 , the more accurate the model is.

Model validation is a process of demonstrating that a model is capable of making accurate predictions for periods outside a calibration period (Refsgaard and Knudsen, 1996). We validated the model using a nine year (2001-2009) evapotranspiration (ET) data set from one station in the north eastern part of the basin (Fig. 9a and b). Based
HESSD

8, 8737-8792, 2011

\section{Water balance modelling in a semi-arid environment}

D. Deus et al.

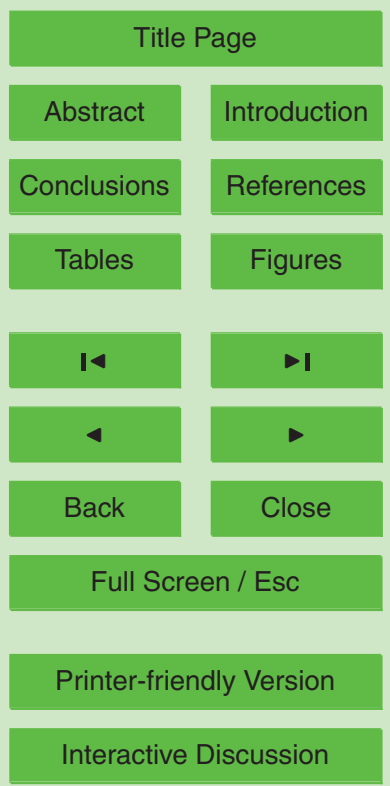


on the Pearson correlation, observed and simulated actual evapotranspiration are interrelated with a correlation coefficient, $R=0.82$ and the coefficient of determination, $R^{2}=0.7$. We observed that the model slightly underestimates ET during periods with a low ET rate. This might be attributed to the accuracy of satellite observation data used.

\section{Modelling results and discussion}

\subsection{Basin water budget components}

Unfortunately the Lake Manyara water balance has never been calculated. Such calculation is currently essential for the management and sustainable conservation of the lake, and to quantify the effect of human activities and climate change. We simulated the spatial-temporal variation of the water balance components based on the modelling grid cell resolution. For the study period, a mean air temperature of $20^{\circ} \mathrm{C}$ was simulated for the Manyara basin. The annual air temperature ranges from a mean minimum monthly air temperature of $14.4^{\circ} \mathrm{C}$ to a mean maximum of $25.8^{\circ} \mathrm{C}$. In smaller lakes and their catchments, temperature is significant with respect to changes in hydrological quantities and water budget estimations. A temperature rise may cause an increase in both lake evaporation and catchment evapotranspiration. Relative humidity was computed as $82 \%$ in a long term mean ranging between 68 and $92 \%$. Monthly variations in the time series results of the hydrologic water balance variables are presented in Fig. 10. Figure 11 depicts spatial variability of water balance components over the Lake Manyara catchment basin during wet and dry seasons. We observe that runoff and ground water recharge portray a similar trend and fluctuate with rainfall occurrences throughout a year. Figure 12 presents the mean monthly water budget elements in Lake Manyara basin over the study period. In simulations for lakes with a larger relative catchment size, almost half of rainfall in the catchment returns to the atmosphere through evapotranspiration (Cardille et al., 2004). For the Lake Manyara
HESSD

8, 8737-8792, 2011

Water balance

modelling in a

semi-arid

environment

D. Deus et al.

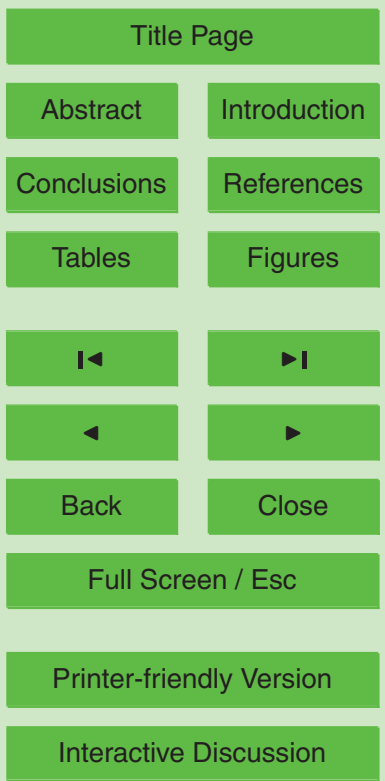


catchment basin about $108 \%$ of the total inflow to the catchment was lost through evapotranspiration during the study period (Table 2).

\subsubsection{Precipitation}

In the Manyara basin, as in other semi-arid regions, precipitation events are of short 5 duration and high intensity and normally characterized by high spatial and temporal variability. We employed the TRMM 3B43 V6 dataset to characterise the water balance elements in the study. The monthly distribution of TRMM data displays a comparable trend with the observed rainfall (Fig. 4). The mean annual rainfall was estimated as $611.6 \mathrm{~mm} \mathrm{yr}^{-1}$ ranging between 379 and $927 \mathrm{~mm} \mathrm{yr}^{-1}$. The mean monthly rainfall 10 is computed to be $51 \mathrm{~mm} \mathrm{month}^{-1}$ over the study period. The spatial distribution of annual precipitation varies between 545 and $645 \mathrm{~mm} \mathrm{yr}^{-1}$ (Fig. 12), with most rainfall events occurring during the wet season. During the wet season a maximum of $87 \mathrm{~mm}$ average monthly precipitation per season is observed to rain on the southern part of the lake and this decrease to the northern part of the catchment. The catchment receives average rainfall ranging from $7 \mathrm{~mm}$ to $11 \mathrm{~mm}$ per month during the dry season. Trend analysis of rainfall results indicates that much rainfall occurred in November and December 2002 and the November 2006 to May 2007 rainy season (Fig. 10). We argue that these events could be due to forcing by the strong Indian Ocean Dipole (IOD) as noted by Becker et al. (2010).

\subsubsection{Evapotranspiration (ET)}

Evapotranspiration is often the largest percentage component of the water balance outflow parameter and hence its accurate determination is crucial for realistic water budget estimation. Around $90 \%$ or more of annual rainfall in semi-arid regions can be lost through evapotranspiration (Wilcox et al., 2003). Estimation of evapotranspiration provides a better understanding of the relationships between water balance and climate. It is predictable that climate change will impact the global hydrologic cycle and
HESSD

8, 8737-8792, 2011

\section{Water balance modelling in a semi-arid environment}

D. Deus et al.

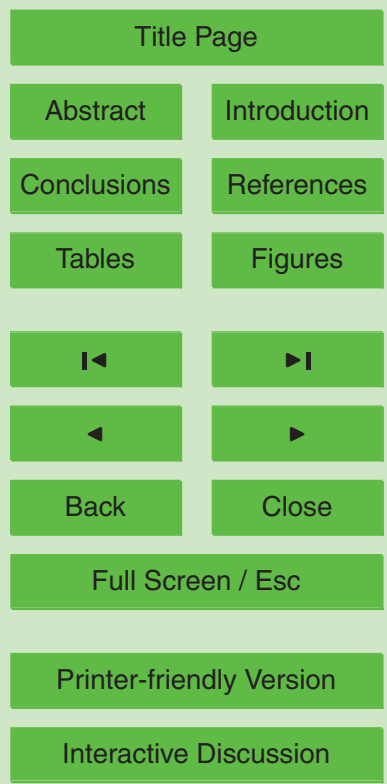


intensify evapotranspiration globally and hence influence water resources (Khan et al., 2011; Meehl et al., 2007; Huntington, 2006). From our work, the mean annual potential evapotranspiration (PET) of the Lake Manyara catchment is $1120 \mathrm{~mm} \mathrm{yr}^{-1}$, varying between 1004 and $1221 \mathrm{~mm} \mathrm{yr}^{-1}$. This indicates that potential evapotranspiration is

5 nearly twice the mean annual and monthly precipitation in the catchment. The mean monthly potential evapotranspiration is computed to be $93 \mathrm{~mm} \mathrm{month}^{-1}$. The spatial distribution of annual potential evapotranspiration ranges from 669 to $1992 \mathrm{~mm} \mathrm{yr}^{-1}$ (Fig. 12). The highlands give a minimum potential evapotranspiration in the catchment compared to the lowlands where the maximum potential evapotranspiration values oc10 cur (Fig. 12).

In semi-arid regions actual evapotranspiration (AET) is a key component in the hydrological cycle and may account for more than $90 \%$ of precipitation (Pilgrim et al., 1988). We estimate the actual evapotranspiration to be $665 \mathrm{~mm} \mathrm{yr}^{-1}$, ranging between 573 and $702 \mathrm{~mm} \mathrm{yr}^{-1}$, and a mean monthly AET of $55 \mathrm{~mm} \mathrm{month}^{-1}$. The actual ET contributes $98.12 \%$ of the outflow parameter in the catchment (Table 2). Spatial distributions of the annual actual ET vary between 421 and $1384 \mathrm{~mm} \mathrm{yr}^{-1}$ (Fig. 12) with an average of 45 to $141 \mathrm{~mm} \mathrm{month}^{-1}$ during the wet seasons. During the dry season the actual evapotranspiration ranges between 17 and $109 \mathrm{~mm} \mathrm{month}^{-1}$ over the study period. The potential evapotranspiration is higher in the dry season. Conversely, the actual evapotranspiration values are almost identical for both dry and wet seasons. In general, evapotranspiration does not vary much as rainfall.

\subsubsection{Runoff}

Runoff is a unique hydrological variable and the last outcome of a large number of flow processes both vertical and horizontal within the entire catchment. Significant amounts of surface runoff occur in the highlands compared to lowlands. The runoff

distribution increases in relation to the catchment altitude variation. The mean annual runoff is estimated to be $12.73 \mathrm{~mm} \mathrm{yr}^{-1}$ varying between 0.261 and $74.94 \mathrm{~mm} \mathrm{yr}^{-1}$. A monthly mean runoff of $1.06 \mathrm{~mm} \mathrm{month}^{-1}$ was calculated for the Manyara catchment.

\section{6}

HESSD

8, 8737-8792, 2011

\section{Water balance modelling in a semi-arid environment}

D. Deus et al.

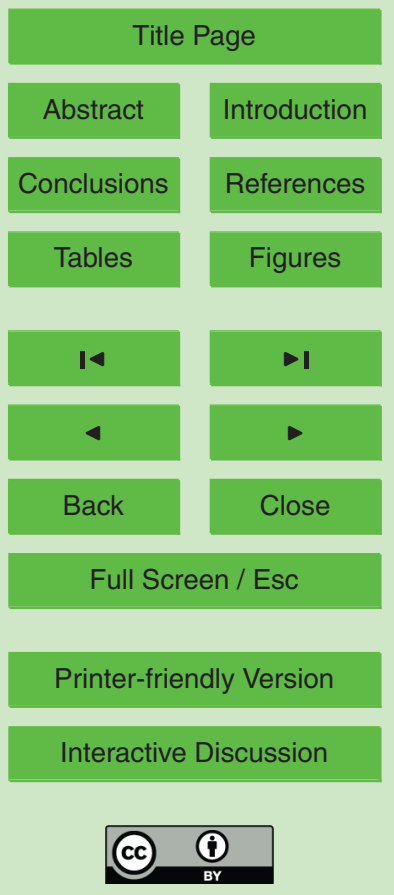


The mean wet season runoff was calculated as $12.23 \mathrm{~mm} \mathrm{month}^{-1}$ and for the dry season $0.489 \mathrm{~mm}$ month $^{-1}$. The spatial distribution of annual runoff varies from 0 to $260 \mathrm{~mm} \mathrm{yr}^{-1}$ (Fig. 12) and most runoff occurs during the wet season. Wet season runoff values range from 0 to $242 \mathrm{~mm}$ month $^{-1}$ and the dry season from -0.1 to

$512 \mathrm{~mm} \mathrm{month}^{-1}$. Discharge from the catchment contributed $2.07 \%$ of the total annual outflow water balance component over the study period (Table 2). A huge quantity of runoff was calculated for January 2007 (Fig. 10). We argue that this might be attributed to forcing by the strong 2006 Indian Ocean Dipole (IOD).

We used an annual hysteresis loop based on concentration-discharge hysteresis analysis to check the rain-runoff relationship in the catchment and perform a linear fitting (Evans and Davies, 1998; Chanat et al., 2002). We observed a yearly anticlockwise hysteresis loop (Fig. 13), which indicates that the discharge values respond to precipitation events occurring across the catchment. The annual cycle shows that runoff values for the rainy season (November-May) are relatively high compared to the dry season (June-October), with the lowest mean monthly discharge values detected in October. The positioning of precipitation and specific discharge along the line of fit indicates a direct relationship of rainfall and discharge. A shift of any of the precipitation-discharge pairs to an increase of precipitation indicates a storage or retention while a shift toward discharge increase indicates the release of water from the catchment. We identify that there is no direct dependency between precipitation and discharge. As visible in Fig. 13 there is a shift towards more precipitation. This means that most of the incoming water from precipitation is either stored in the catchment or lost through evapotranspiration during both wet and dry seasons. We suspect the latter, based on the fact that evapotranspiration accounts for $98.13 \%$ of the total outflow 25 from the catchment basin.
HESSD

8, 8737-8792, 2011

\section{Water balance modelling in a semi-arid environment}

D. Deus et al.

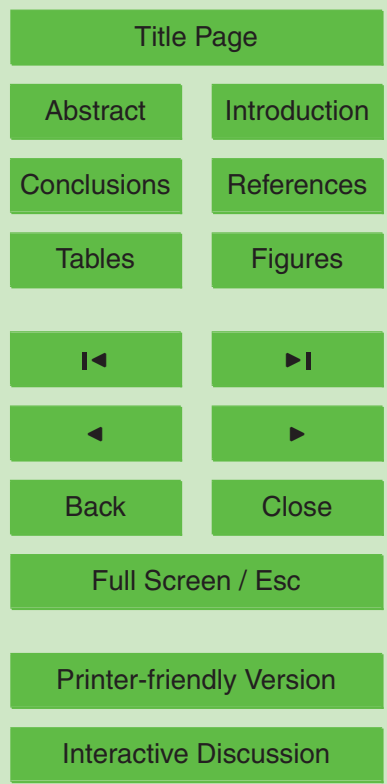




\subsubsection{Ground water recharge and storage}

In a semi-arid environment groundwater is the only water resource that is available throughout the year and hence its calculation is crucial for catchment water balance estimation and sustainable management. Groundwater recharge and storage are im5 portant in water budget evaluation but challenging to quantify. Recharge cannot be measured directly and is a component of the hydrological budget that is difficult to predict. This is predominantly true for semi-arid regions where recharge may be as low as $1 \%$ of the precipitation (Bouwer, 1989; Andersen, 2008). In semi-arid areas ET captures most of the water entering the soil, and recharge occurs only during extreme rainfall events (Pilgrim et al., 1988).

We estimate a mean yearly ground water recharge and storage of 1.67 and $9.6 \mathrm{~mm} \mathrm{yr}^{-1}$ respectively. The mean annual ground water recharge accounts for $0.05 \%$ of the total inflow to the catchment (Table 2). Figure 12 presents a spatial distribution of the groundwater recharge and storage in the catchment over the study period. The annual ground water recharge fluctuates between 0 and $47 \mathrm{~mm} \mathrm{yr}^{-1}$. The annual catchment ground water storage ranges from -3 to $271 \mathrm{~mm} \mathrm{yr}^{-1}$. During the wet season the catchment ground water recharge ranges from 0 to $10 \mathrm{~mm}$ while the storage lies between 0 and $37 \mathrm{~mm}$ per month. In dry seasons the catchment basin is completely dry with no ground water recharge; however during this period ground water storage varies from -0.09 to $11.1 \mathrm{~mm} \mathrm{month}^{-1}$. As depicted in Fig. 10, groundwater recharge typically increases as runoff increases. Both temperature and rainfall have an impact on groundwater recharge. Based on Figs. 10 and 13, it appears that the temporal variation of soil and moisture in terms of relative soil water, ground water recharge and storage is caused by climate variability, whereas their spatial variation depends on the

\section{HESSD}

8, 8737-8792, 2011

\section{Water balance modelling in a semi-arid environment}

D. Deus et al.

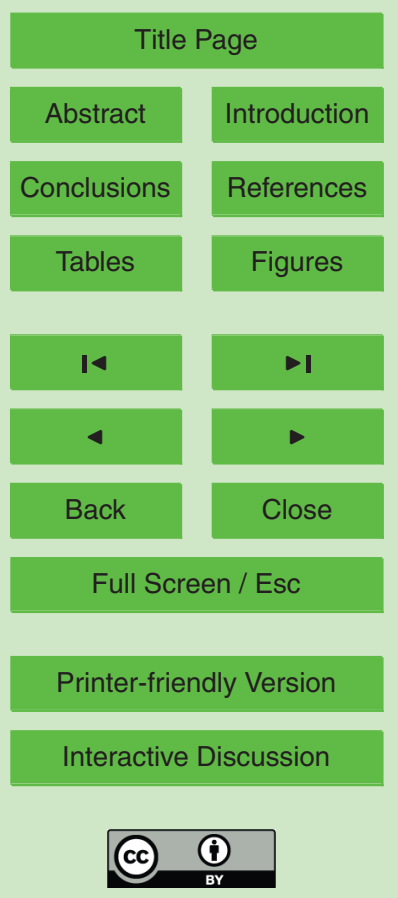




\subsection{Lake water balance and comparison}

Water stored in a lake is a function of surface water, ground water and soil moisture. Changes in the lake level are directly related to the variation of the water stored in its basin. Due to the fact that the lake is supplied both by rainfall and stream inflow, a 5 reduction in basin water storage causes a lake level decrease (Awange et al., 2008). An examination of the stored water in Lake Manyara provides water resource managers and planners with information about the water stored within the basin.

Lake morphometry influences a lake's water balance by affecting the evaporating surface area for a given lake volume and the portion of the lake bed that transmits ground water flow in and out of the lake (Cardille et al., 2004). Since Lake Manyara is un-gauged we estimated the lake capacity using the lake surface area-volume relationship at different depths by applying lake bathymetry measurements surveyed in 2010 as:

$V=\frac{1}{2} H\left(A_{1}+A_{2}\right)$

15 where $V=$ volume of water; $H=$ difference in depth between two successive depth contours; $A_{1}=$ area of the lake within the outer depth contour being considered; $A_{2}=$ area of the lake within the inner contour line under consideration. The procedure consists of determining the volumes of successive layers of water and then summing these volumes to obtain the total volume of the lake (Taube, 2000). Lake bathymetry is the study of underwater depth. The Lake Manyara bathymetric map (Fig. 14a) has been generated using an echo sounder, which measures the depth of the lake floor. The echo sounder was attached with a Global Positioning System (GPS) device to capture the horizontal position of specific points. The depth of the deepest point was $1.18 \mathrm{~m}$ (Fig. 14b) and the height above the mean sea level at this point is $957 \mathrm{~m}$. The horizontal datum for mapping is the global datum, based on the World Geodetic Reference System 1984 (WGS84) reference ellipsoid. Figure 14a-c present a bathymetric map,

\section{Water balance modelling in a semi-arid environment}

D. Deus et al.

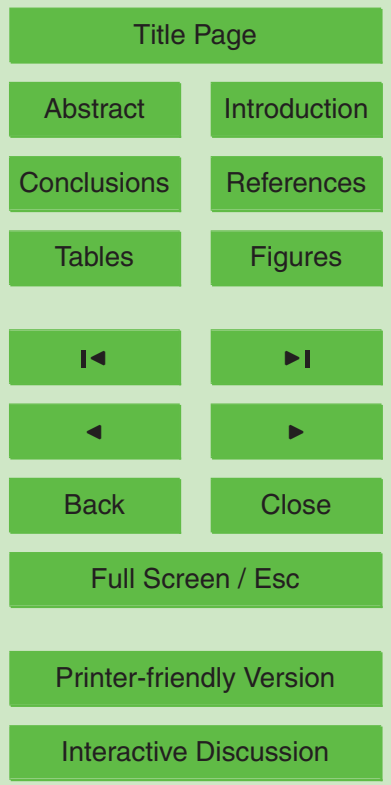


lake morphology and a relation between lake surface area and volume computed at different lake levels respectively.

Figure 15 shows water storage change in the lake in relation to the distribution of seasonal precipitations. The mean monthly lake storage change is estimated to be $5-0.02 \mathrm{~km}^{3}$ with a range of -0.04 to $0.04 \mathrm{~km}^{3}$ over the study period. Seasonal precipitation influences lake storage for lakes without outflow. As shown in Fig. 15, the Lake Manyara storage volume is directly proportional to rainfall, thus lake storage decreases as the amount of rainfall decreases during dry seasons. Changes in lake level or relative water depth, which are both functions of Lake surface and volume, provide 10 information about changes in water balance.

The mean annual values of the key water balance parameter for the lake from 2001 to 2009 are given in Table 2 . We calculated the annual mean rainfall over the lake to be $0.216 \mathrm{~km}^{3} \mathrm{yr}^{-1}$, evaporation was estimated as $0.424 \mathrm{~km}^{3} \mathrm{yr}^{-1}$ and inflow to the lake was estimated as $0.24 \mathrm{~km}^{3} \mathrm{yr}^{-1}$. Inflow consists of a contribution from streams and 15 underground springs. Rainfall contributes $47 \%$ to the total inflow while evaporation from the lake was the largest component of the water balance, accounting for $100 \%$ of total water loss. Inflow to the lake contributes $53 \%$ of the total inflow parameter. For Lake Manyara only $7 \%$ of the total inflow did not evaporate during the study period. Figure 16 illustrates the mean monthly water balance components for Lake Manyara over the study period. Figure 17 presents the catchment water balance as a weighted combination of $P-\mathrm{ET}$ and $P-E$ curves. Cardille et al. (2004) pointed out that the water balance of a lake catchment of large area relative to the area of the lake is more linked to precipitation minus evapotranspiration.

\section{Lake water balance and GRACE equivalent water thickness comparison}

25 We have compared the GRACE total water storage (TWS) as equivalent water thickness (EWT) with the simulated water balance. Rodell and Famigliet (2001) pointed out that the data resolution of GRACE is not sufficient to study basins smaller than $200000 \mathrm{~km}^{2}$. Lake Manyara basin covers $18763 \mathrm{~km}^{2}$, with Lake Manyara occupying

\section{HESSD}

8, 8737-8792, 2011

\section{Water balance modelling in a semi-arid environment}

D. Deus et al.

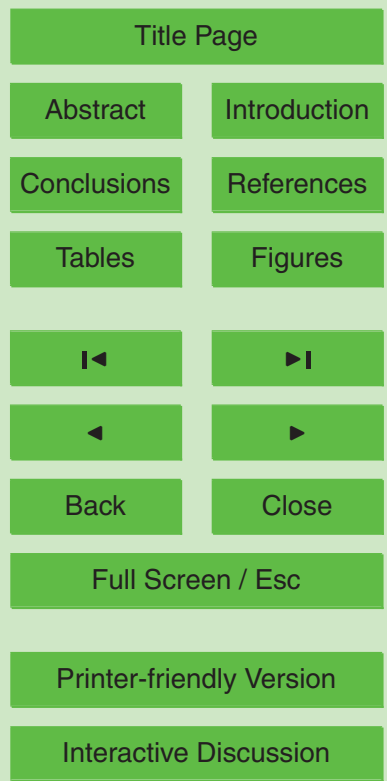


$465.96 \mathrm{~km}^{2}$. Nevertheless, the latest GRACE data has improved precision and resolution and permits the study of smaller basins (Becker et al., 2010). We extracted a time series of GRACE equivalent water thickness for a single pixel on the Lake from the land mass grid and applied the scale factor. Figure 18a shows the lake water 5 balance volume superimposed on to the GRACE equivalent water thickness. Due to frequent fluctuations in GRACE data we applied a 12 month exponential moving average (EMA) to smooth the dataset and elude small scale noise. Exponential moving average is a kind of infinite impulse response filter that applies weighting factors that decrease exponentially. The weighting for each older data point decreases exponentially, never reaching zero. The exponential moving average formula gives more weight to recent data in the series and less weight to older data. Figure 18b presents the Lake water balance volume overlaid by the smoothed GRACE equivalent water thickness. The exponentially smoothed GRACE equivalent water thickness portrays a Pearson's correlation coefficient of 0.68 (Fig. 19).

15 We observe abrupt change in GRACE equivalent water thickness and in the lake water balance volume between 2006 and 2007. Similarly, Becker et al. (2010) discovered sudden changes in GRACE total water storage and water surface volume for several lakes in East Africa for the same period. The variations are directly correlated to the strong positive and negative episodes of the Indian Ocean Dipole (IOD) in 2006-2007.

20 The Indian Ocean Dipole is an ocean-atmosphere interaction, over the Indian Ocean, creating alternating positive and negative Sea Surface Temperature (SST) anomalies. During the positive phase there is flooding in East Africa. The the Indian summer monsoon is more intesnse than normal and there is drought in Indonesia and in several regions of Australia (Becker et al., 2010; Birkett et al., 1999; Reason, 2002).

25 We used a trend analysis to compare the simulated lake water balance with GRACE equivalent water thickness. To quantify whether trends are significant or not a signal to noise ratio (SNR) was calculated as the ratio between the estimated trend and the standard deviations of the anomalies. Signal to noise ratio values $\geq 1$ indicate a significant trend (Krause et al., 2010; Bormann, 2005). Unfiltered GRACE equivalent

\section{HESSD}

8, 8737-8792, 2011

\section{Water balance modelling in a semi-arid environment}

D. Deus et al.

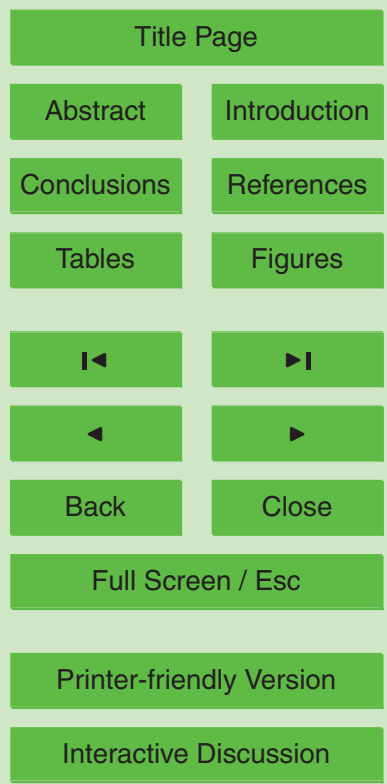


water thickness data gave a trend that was not significant $(S N R=0.16)$. By contrast, smoothed GRACE equivalent water thickness exhibited a significant linear trend $(S N R=3.49)$. The monthly anomaly was calculated by subtraction of the 2001-2009 monthly mean from the monthly EWT data.

$5 \quad$ Using satellite altimetry we compared Lake Manyara water level fluctuations with with two lakes in the vicinity: Lake Victoria and Rukwa (Fig. 20). Satellite altimetry has been employed to monitor water levels of lakes, flood plains and wetlands over the last two decades (Becker et al., 2010; Hwang et al., 2011; Frappart et al., 2008; Calmant et al., 2008; Crétaux and Birkett, 2006; Birkett et al., 1999; Swenson and Wahr, 2009; 10 Mercier et al., 2002). As it can be observed in Fig. 20, the Lake Manyara water level varies in similar fashion to other lakes in the region.

\section{Conclusions and outlook}

In this paper we presented the result of a water balance modelling of a semi-arid lake catchment. We used remote sensing measurements combined with ground data to attain a reasonable simulation of the surface water cycle over the study period. The results were validated by comparing evapotranspiration and the lake water balance with observed evapotranspiration and satellite gravimetry GRACE equivalent water thickness data respectively. The overall agreement between prediction and measurement from in-situ and satellite observations confirm the validity of the annual water balance

of Lake Manyara basin obtained from the averaged monthly values. The changes in water balance including the dramatic rise in 2006-2007, are attributed to changes in climatic forcing parameters. We conclude that the most crucial factor controlling the water balance and lake level is precipitation.

We show that an estimation of water budget elements for a lake catchment in a semi25 arid region with scarce existing data is possible using remote sensing approach. Our hydrological model reasonably captured the spatial and temporal variability of the water balance parameters in the catchment. Therefore, the model is suitable for hydrological

\section{2}

HESSD

8, 8737-8792, 2011

\section{Water balance \\ modelling in a semi-arid environment}

D. Deus et al.

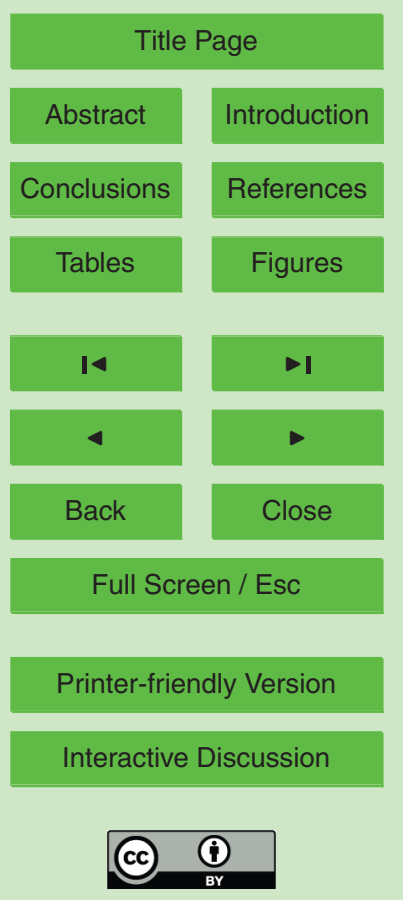


modelling in data scarce semi-arid basins due to its capability to incorporate both ground and remote sensing measurements. There is a great potential to make use of GRACE equivalent water thickness land mass grid datasets in smaller un-gauged lakes and basins in semi-arid environments.

5 In the future in-situ runoff data for model validation might be available, and this will help us to re-analyse the model structure and parameterization. Additionally, there is a need for explorative ground water studies in the Lake Manyara basin.

Acknowledgements. We are indebted to the DAAD (German academic exchange service) for supporting the $\mathrm{PhD}$ research project of the first author at the Technische Universität 10 Bergakademie Freiberg, Germany. We would like to acknowledge the Tanzania Meteorological Agency for providing us with meteorological datasets. We acknowledge the accessibility of GRACE land data. The data were processed by Sean Swenson and supported by the NASA MEASURES Program. We also express our gratitude to Adam Szulc for proofreading the manuscript.

Adler, R. F., Huffman, G. J., Chang, A., Ferraro, R., Xie, P., Janowiak, J., Rudolf, B., Schneider, U., Curtis, S., Bolvin, D., Gruber, A., Susskind, J., Arkin, P., and Nelkin, E.: The version 2 Global Precipitation Climatology Project (GPCP) monthly precipitation analysis (1979Present), J. Hydrometeorol., 4, 1147-1166, 2003.

20 Allen, R. G., Pereira, L. S., Raes, D., and Smith, M.: Crop Evapotranspiration: Guidelines for Computing Crop Water Requirements, FAO Irrigation and drainage paper 56, Food and Agriculture Organization of the United Nations, Rome, Italy, 1998.

Andermann, C., Bonnet, S., and Gloaguen, R.: Evaluation of precipitation data sets along the Himalayan front, Geochem. Geophy. Geosy., 12, Q07023, doi:07010.01029/02011GC003513, 2011.

Andersen, F. H.: Hydrological modelling in a semi-arid area using remote sensing data, Doctoral Thesis, Department of Geography and Geology, University of Copenhagen, Copenhagen, 2008.

\section{HESSD}

8, 8737-8792, 2011

\section{Water balance modelling in a semi-arid environment}

D. Deus et al.

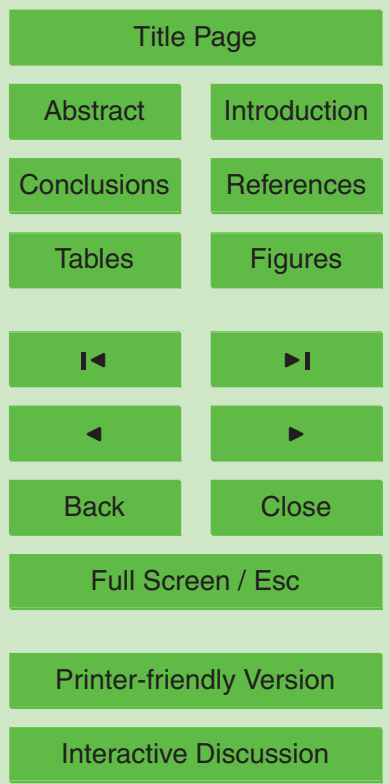


Awange, J. L., Sharifi, M., Ogonda, G., Wickert, J., Grafarend, E. W., and Omulo, M.: The falling Lake Victoria water levels: GRACE, TRIMM and CHAMP satellite analysis of the lake basin, Water Resour. Manage., 22, 775-796, doi:10.1007/s11269-007-9191-y, 2008.

Awulachew, S. B.: Modelling natural conditions and impacts of consumptive water use and 5 sedimentation of Lake Abaya and Lake Chamo, Ethiopia, Lakes Reserv. Res. Manage., 11, 73-82, 2006.

Barnes, W. L., Pagano, T. S., and Salomonson, V. V.: Prelaunch characteristics of the Moderate Resolution Imaging Spectroradiometer (MODIS) on EOS-AM1, IEEE T. Geosci. Remote, 36, 1088-1100, 1998.

10 Becker, M., LLovel, W., Cazenave, A., Güntner, A., and Cretaux, J.: Recent hydrological behavior of the East African great lakes region inferred from GRACE, satellite altimetry and rainfall observations, Comptes Rendus Geoscience, 342, 223-233, doi:10.1016/j.crte.2009.12.010, 2010.

Birkett, C., Murtugudde, R., and Allan, T.: Indian Ocean climate event brings floods 15 to East Africa's lakes and the Sudd Marsh, Geophys. Res. Lett., 26, 1031-1034, doi:1010.1029/1999GL900165, 1999.

Böhme, B., Steinbruch, F., Gloaguen, R., Heilmeier, H., and Merkel, B.: Geomorphology, hydrology, and ecology of Lake Urema,central Mozambique, with focus on lake extent changes, Phys. Chem. Earth, 31, 745-752, 2006.

20 Bormann, H.: Evaluation of hydrological models for scenario analyses: signal-to-noise-ratio between scenario effects and model uncertainty, Adv. Geosci., 5, 43-48, doi:10.5194/adgeo5-43-2005, 2005.

Bouwer, H.: Estimating and enhancing groundwater recharge, in: Groundwater Recharge, edited by: Sharma, M. L., Balkema, Rotterdam, The Netherlands, p.1, 1989.

Breuer, L., Eckhardt, K., and Frede, H.-G.: Plant parameter values for models in temperate climates, Ecol. Modell., 169, 237-293, doi:10.1016/S0304-3800(03)00274-6, 2003.

Calmant, S., Seyler, F., and Cretaux, J.: Monitoring continental surface waters by Satellite Altimetry, Surv. Geophys., 29, 247-269, doi:210.1007/s10712-10008-19051-10711, 2008.

Cardille, J., Coe., M. T., and Vano., J.: Impacts of climate variation and catchment area on water balance and lake hydrologic type in groundwater-dominated systems: A generic lake model., Earth Interactions, 8, 1-24., 2004.

\section{HESSD}

8, 8737-8792, 2011

\section{Water balance \\ modelling in a \\ semi-arid \\ environment}

D. Deus et al.

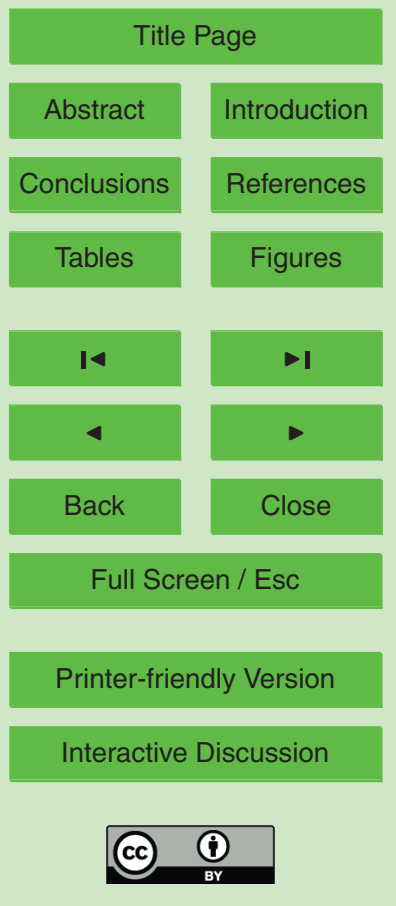


Casey, M., Ebinger, C., Keir, D., Gloaguen, R., and Mohamed, F.: Strain accommodation in transitional rifts: extension by magma intrusion and faulting in Ethiopian rift magmatic segments, Geolog. Soc. London, Special Publications, 259, 143-163, doi:110.1144/GSL.SP.2006.1259.1101.1113, 2006.

5 Chanat, J. G., Rice, K. C., and Hornberger, G. M.: Consistency of patterns in concentrationdischarge plots, Water Resour. Res., 38, 1147, doi:1110.1029/2001WR000971, 2002.

Chen, J. M., Liu, J., Cihlar, J., and Goulden, M. L.: Daily canopy photosynthesis model through temporal and spatial scaling for remote sensing applications, Ecol. Modell., 124, 99-119, 1999.

10 Copeland, S. R.: Potential hominin plant foods in northern Tanzania: semi-arid savannas versus savanna chimpanzee sites, J. Human Evol., 57, 365-378, 2009.

Crétaux, J. and Birkett, C.: Lake studies from satellite radar altimetry, Comptes Rendus Geosciences, 338, 1098-1112, 2006.

Dingman, S. L.: Physical hydrology, Prentice Hall, Upper Saddle River, 2002.

Evans, C. and Davies, T. D.: Causes of concentration/discharge hysteresis and its potential as a tool for the analysis of episode hydrochemistry, Water Resour. Res., 34, 129-137, 1998.

FAO, IIASA, ISRIC, ISSCAS, and JRC: Harmonized World Soil Database (version 1.1), FAO, Rome, Italy and IIASA, Laxenburg, Austria, 2009.

Frappart, F., Papa, F., Famiglietti, J. S., Prigent, C., Rossow, W. B., and Seyler, F.: Interannual variations of river water storage from a multiple satellite approach: A case study for the Rio Negro River basin, Atmospheres, J. Geophys. Res., 113, D21104, doi:21110.21029/22007JD009438, 2008.

Ge, J., Qi., J., Lofgren, B. M., Moore, N., Torbick, N., and Olson, J. M.: Impacts of land use/cover classification accuracy on regional climate simulations, J. Geophys. Res., 112 D05107, doi:05110.01029/02006JD007404, 2007.

Gebremichael, M., Over, T. M., and Krajewski, W. F.: Comparison of the scaling characteristics of rainfall derived from spacebased and ground-based radar observations, J. Hydrometeorol., 7, 1277-1294, doi:1210.1175/JHM1549.1271, 2006.

Goerner, A., Jolie, E., and Gloaguen, R.: Non-climatic growth of the saline Lake Beseka, 30 Main Ethiopian Rift, J. Arid Environ., 73, 287-295, doi:0110.1016/j.jaridenv.2008.0109.0015, 2008.
HESSD

8, 8737-8792, 2011

\section{Water balance \\ modelling in a \\ semi-arid \\ environment}

D. Deus et al.

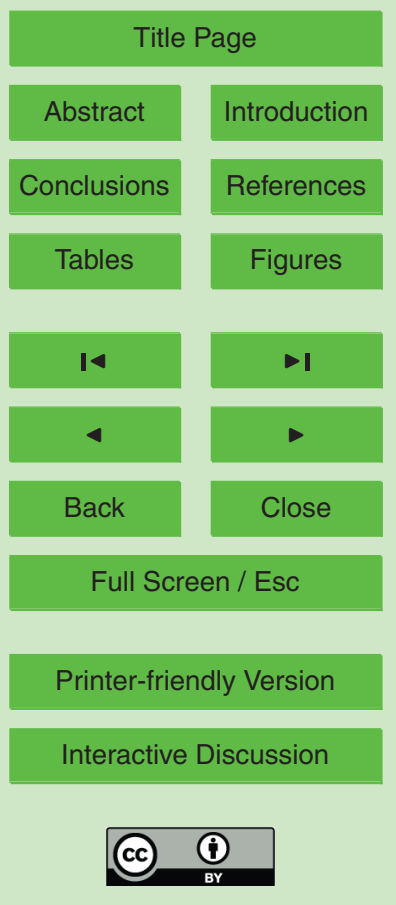


Guenther, B., Godden, G. D., Xiong, X., Knight, E. J., Qiu, S.-Y., Montgomery, H., Hopkins, M. M., and Hao, Z.: Prelaunch algorithm and data format for the level 1 calibration product for the EOS-AM1 Moderate Resolution Imaging Spectroradiometer (MODIS), IEEE T. Geosci. Remote, 36, 1142-1151, 1998.

5 Güntner, A. and Bronstert, A.: Representation of landscape variability and lateral redistribution processes for large-scale hydrological modelling in semi-arid areas, J. Hydrol., 297, 136161, 2004.

Güntner, A., Carlos de araújo, J., and Bronstert, A.: Simple water balance modelling of surface reservoir systems in a large data-scarce semi-arid region, Hydrolog. Sci., 49, 901-918, 2004.

Hildebrand, P. H.: Toward an improved understanding of the global fresh water budget. A symposium on living with a limited water supply 85th AMS Annual Meeting, 9-13 January, San Diego, 2005.

Hole-filled SRTM for the globe Version 4: available from the CGIAR-CSI SRTM $90 \mathrm{~m}$ Database: http://srtm.csi.cgiar.org (last access: 5 June 2010), 2008.

Huffman, G. J., Adler, R. F., Rudolf, B., Schneider, U., and Keehn, P. R.: Global precipitation estimates based on a technique for combining satellite-based estimates, rain-gauge analysis, and NWP model precipitation, J. Climatol., 8, 1284-1295, 1995.

Huffman, G. J., Adler, R. F., Bolvin, D. T., Gu, G. J., Nelkin, E. J., Bowman, K. P., Hong, Y., Stocker, E. F., and Wolff, D. B.: The TRMM multisatellite precipitation analysis (TMPA): Quasiglobal, multiyear, combined-sensor precipitation estimates at fine scales, J. Hydrometeorol., 8, 38-55, doi:10.1175/JHM560.1, 2007.

Huntington, T.: Evidence for intensification of the global water cycle: Review and synthesis, J. Hydrol., 319, 83-95, 2006.

Hwang, C., Kao, Y., and Tangdamrongsub, N.: A Preliminary Analysis of Lake Level and Water Storage Changes over Lakes Baikal and Balkhash from Satellite Altimetry and Gravimetry, Terr. Atmos. Ocean. Sci., 22, 97-108, doi:110.3319/TAO.2010.3305.3319.3301(TibXS), 2011.

Iqbal, M.: An introduction to solar radiation, New York Academic Press, New York, 1983.

30 Jensen, M. E., Burman, R. D., and Allen, R. G. E.: Evaporation and irrigation water requirements: Manual of Practice, New York, 360, 1990.

Kaspar, F., Cubasch, U., and Offenbach, G.: Simulation of East African precipitation patterns with the regional climate model CLM, Meteorol. Z., 17, 511-517, 2008.
HESSD

8, 8737-8792, 2011

\section{Water balance \\ modelling in a semi-arid environment}

D. Deus et al.

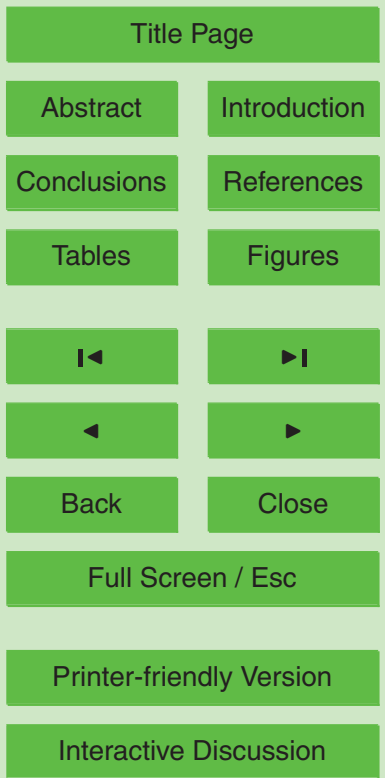


Kebede, S., Travia, Y., Alemayehub, T., and Marca, V.: Water balance of Lake Tana and its sensitivity to fluctuations in rainfall, Blue Nile basin, Ethiopia, J. Hydrol., 316, 233-247, 2006.

Keranen, K., Klemperer, S. L., and Gloaguen, R.: Three-dimensional seismic imaging of a protoridge axis in the Main Ethiopian rift, Geology, 32, 949, doi:910.1130/G20737.20731, 52004.

Khan, S. I., Adhikari, P., Hong, Y., Vergara, H., F Adler, R., Policelli, F., Irwin, D., Korme, T., and Okello, L.: Hydroclimatology of Lake Victoria region using hydrologic model and satellite remote sensing data, Hydrol. Earth Syst. Sci., 15, 107-117, doi:10.5194/hess-15-107-2011, 2011.

10 Kralisch, S. and Krause, P.: JAMS: A Framework for Natural Resource Model Development and Application, Proceedings of the iEMSs Third Biannual Meeting, 2006.

Krause, P. and Hanisch, S.: Simulation and analysis of the impact of projected climate change on the spatially distributed waterbalance in Thuringia, Germany, Adv. Geosci., 21, 33-48, doi:10.5194/adgeo-21-33-2009, 2009.

15 Krause, P., Biskop, S., Helmschrot, J., Flügel, W.-A., Kang, S., and Gao, T.: Hydrological system analysis and modelling of the Nam Co basin in Tibet, Adv. Geosci., 27, 29-36, doi:10.5194/adgeo-27-29-2010, 2010.

Kummerow, C., Barnes, W., Kozu, T., Shiue, J., and Simpson, J.: The tropical rainfall measuring mission (TRMM) sensor package, J. Atmos. Ocean. Tech., 15, 809-817, 1998.

20 Kurz, T., Gloaguen, R., Ebinger, C., Casey, M., and Abebe, B.: Deformation distribution and type in the Main Ethiopian Rift (MER): A remote sensing study, J. Afr. Earth Sci., 48, 100114, doi:110.1016/j.jafrearsci.2006.1010.1008, 2007.

Lambin, E. F.: Monitoring forest degradation in tropical regions by remote sensing: Some methodological issues, Global Ecol. Biogeogr., 8, 191-198, 1999.

Liu, Y. B., Batelaan, O., De Smedt, F., and Poórová, J. A. V. L.: Automated calibration applied to a GIS-based flood simulation model using PEST, in: Floods, from Defence to Management, edited by: van Alphen, J., van Beek, E., and Taal, M., Taylor-Francis Group, London, 317326, 2005.

Loveland, T. R. and Belward, A. S.: The IGBP-DIS Global $1 \mathrm{~km}$ Land Cover Data Set, DISCover First Results, Int. J. Remote Sens., 18, 3289-3295, 1997.

Meehl, G., Stocker, T., Collins, W., Friedlingstein, P., Gaye, A., Gregory, J., Kitoh, A., Knutti, R., Murphy, J., and Noda, A.: Global climate projections Climate Change 2007: The Physical Science Basis, Contribution of Working Group I to the Fourth Assessment Report of the

\section{7}

\section{HESSD}

8, 8737-8792, 2011

\section{Water balance \\ modelling in a \\ semi-arid \\ environment}

D. Deus et al.

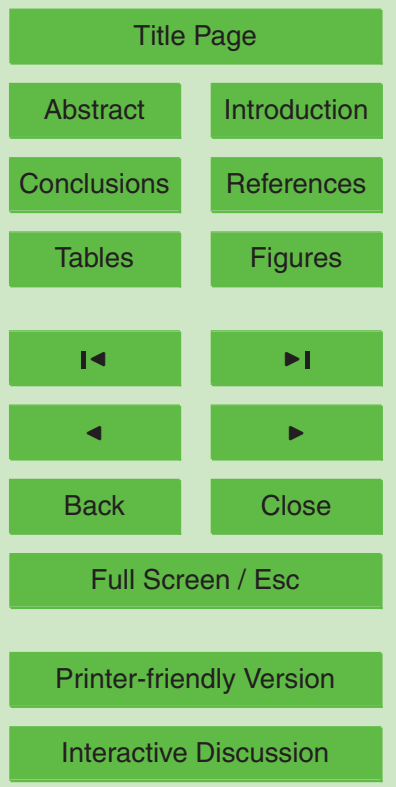


Intergovernmental Panel on Climate Change, edited by: Solomon, S., Qin, D., Manning, M., Chen, Z., Marquis, M., Averyt, K., Tignor, M., and Miller, H. L, Cambridge University Press, New York, 747-845, 2007.

Mercier, F., Cazenave, A., and Maheu, C.: Interannual lake level fluctuations (1993-1999) 5 in Africa from Topex/Poseidon: connections with ocean-atmosphere interactions over the Indian Ocean, Global Planet. Change, 32, 141-163, 2002.

Milzow, C., Krogh, P. E., and Bauer-Gottwein, P.: Combining satellite radar altimetry, SAR surface soil moisture and GRACE total storage changes for hydrological model calibration in a large poorly gauged catchment, Hydrol. Earth Syst. Sci., 15, 1729-1743, doi:10.5194/hess$10 \quad$ 15-1729-2011, 2011.

Nash, J. E. and Sutcliffe, J. V.: River flow forecasting through conceptual models, Part I: A discussion of principles, J. Hydrol., 10, 282-290, 1970.

Pilgrim, D. H., Chapman, T. G., and Doran, D. G.: Problems of rainfallrunoff modelling in arid and semiarid regions/Problèmes de la mise au point de modèles pluie-écoulement dans les régions arides et semi-arides, Hydrolog. Sci. J., 33, 379-400, 1988.

Prigent, C.: Precipitation retrieval from space: An overview, Comptes Rendus Geoscience, 342, 380-389, 2010.

Prins, H. T. and Loth, P. E.: Rainfall patterns as background to plant phenology in northern Tanzania, J. Biogeogr., 15, 451-463, 1988.

20 Ramillien, G., Frappart, F., Cazenave, A., and Güntner, A.: The variation of land water storage from an inversion of 2 years GRACE geoids, Earth Planet. Sci. Lett., 235, 283-301, 2005.

Refsgaard, J. C. and Knudsen, J.: Operational validation and intercomparison of different types of hydrological models, Water Resour. Res., 32, 2189-2202, 1996.

Rodell, M. and Famiglietti, J. S.: An analysis of terrestrial water storage variations in illinois with implications for the gravity recovery and climate experiment (GRACE), Water Resour. Res., 37, 1327-1340, 2001.

Simonsson, L.: Applied Landscape Assessment in a Holistic Perspective,A case study from Babati District, North-central Tanzania, Department of Earth Science, ISSN 1650-1495X, Uppsala University, Uppsala, 2001.

30 Somi, E. J.: Palaeoenvironmental change in central and coastal Tanzania during the Upper Cenozoic, Doctoral University of Stockholm, Stockholm, 1-100, 1993.

\section{HESSD}

8, 8737-8792, 2011

\section{Water balance \\ modelling in a \\ semi-arid \\ environment}

D. Deus et al.

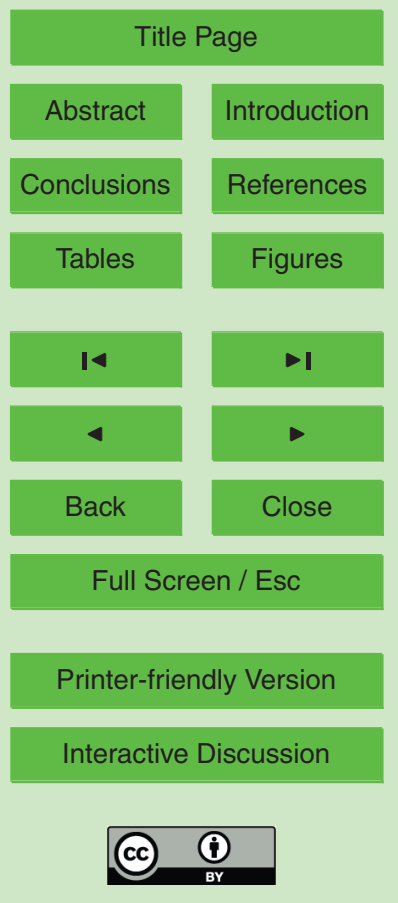


Sorooshian, S., Lawford, R., Try, P., Rossow, W., Roads, J., Polcher, J., Sommeria, G., and Schiffer, R.: Water and energy cycles: investigating the links, World Meteorol. Org. Bull., 54, 58-64, 2005.

Strugnell, N. C., Lucht, W., and Schaaf, C.: A global albedo data set derived from AVHRR data for use in climate simulations, Geophys. Res. Lett., 28, 191-194, 2001.

Swenson, S. and Wahr, J.: Post-processing removal of correlated errors in GRACE data, Geophys. Res. Lett., 33, L08402, doi:08410.01029/02005GL025285, 2006.

Swenson, S. C. and Wahr, J.: Monitoring the water balance of Lake Victoria, East Africa, from space, J. Hydrol., 370, 163-176, doi:0010.1016/j.jhydrol.2009.0003.0008, 2009.

10 Taube, C. M.: Instructions for winter lake mapping, Chapter 12, in: Manual of fisheries survey methods II: with periodic updates, edited by: Schneider, J. C., Michigan Department of Natural Resources, Fisheries Special Report, Ann Arbor, 2000.

Thornthwaite, C.: An approach toward a rational classification of climate, Geogr. Rev., 38, 55-94, 1948.

Troch, P. A.: Data assimilation for regional water balance studies in arid and semi-arid areas (Case study: the Volta basin upstream the Akosombo dam in Ghana), First MSG RAO Workshop Held 17-19 May, 2000CNR, Bologna, Italy, 2000.

Wahr, J., Swenson, S., Zlotnicki, V., and Velicogna, I.: Time-variable gravity from GRACE: first results, Geophys. Res. Lett., 31, L11501, doi:11510.11029/12004GL019779, 2004.

Wan, Z.: New refinements and validation of the MODIS Land-Surface Temperature/Emissivity products, Remote Sens. Environ., 112, 59-74, doi:1016/j.rse.2006.06.026, 2008.

Wan, Z. and Li, Z.-L.: A physics-based algorithm for retrieving land-surface emissivity and temperature from EOS/MODIS data, IEEE T. Geosci. Remote, 35, 980-996, 1997.

Wan, Z., Zhang, Y., Li, Z.-L., Wang, R., Salomonson, V. V., Yves, A., Bosseno, R., and Hanocq, J. F.: Preliminary estimate of calibration of the Moderate Resolution Imaging Spectroradiometer (MODIS) thermal infrared data using Lake Titicaca, Remote Sens. Environ., 80, 497-515, 2002.

Wan, Z., Zhang, Y., Zhang, Q., and Li, Z.-L.: Quality assessment and validation of the MODIS land surface temperature, Int. J. Remote Sens., 25, 261-274, 2004.

30 Wheater, H., Sorooshian, S., and Sharma, K. D.: Hydrological modelling in arid and semi-arid areas, ISBN: 9780521869188, Cambridge University Press, Cambridge, 2007.

Wilcox, B., Seyfried, M., and Breshears, D.: The water balance on rangelands, Encyclopedia of water science, 791-794, doi:710.1081/E-EWS-120010097, 2003.

\section{9}

\section{HESSD}

8, 8737-8792, 2011

\section{Water balance \\ modelling in a \\ semi-arid \\ environment}

D. Deus et al.

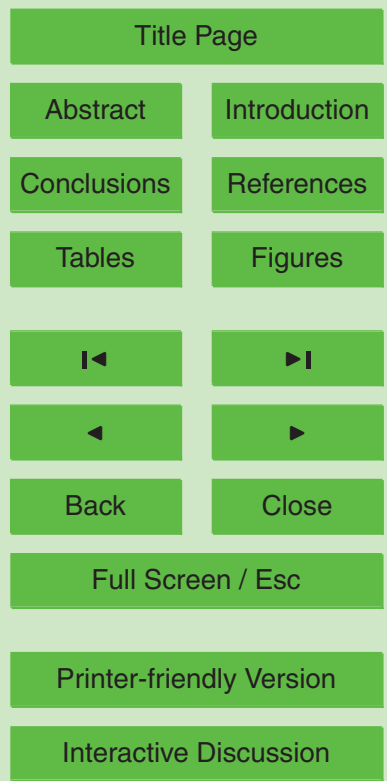


Willmott, C. J., Rowe, C. M., and Mintz, Y.: Climatology of the terrestrial seasonal water cycle, Int. J. Climatol., 5, 589-606, 1985.

Yanda, P. Z. and Madulu., N. F.: Water resource management and biodiversity conservation in the Eastern Rift Valley Lakes, Northern Tanzania, Phys. Chem. Earth, 30, 717-725, doi:710.1016/j.pce.2005.1008.1013, 2005.

Yucel, I.: Effects of Implementing MODIS Land Cover and Albedo in MM5 at Two Contrasting U.S. Regions, J. Hydrometeorol., 7, 1043-1060, 2006.

Zeng, X.: Global Vegetation Root Distribution for Land Modelling, Notes Correspond., J. Hydrometeorol., 2, 525-530, 2001.

\section{HESSD}

8, 8737-8792, 2011

\section{Water balance modelling in a semi-arid environment}

D. Deus et al.

\section{Title Page}

Abstract

Conclusions

Tables

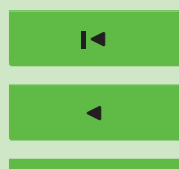

Back
Introduction

References

Figures

$\rightarrow$ I

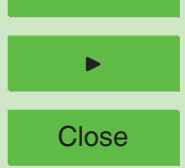

Full Screen / Esc

Printer-friendly Version 


\section{HESSD}

8, 8737-8792, 2011

Table 1. Adopted Albedo, LAI, Rsco, $H_{\max }$ and $R_{\mathrm{Dmax}}$ values for each IGBP land cover type (Source: Strugnell et al., 2001; Yucel, 2006; Lambin, 1999; Breuer et al., 2003; Zeng, 2001; Ge et al., 2007).

\begin{tabular}{lcrccc}
\hline Land Cover Type & Albedo $(\%)$ & $R_{\mathrm{SCO}}\left(\mathrm{sm}^{-1}\right)$ & $\mathrm{LAl}$ & $H_{\max }(\mathrm{m})$ & $R_{\text {Dmax }}(\mathrm{dm})$ \\
\hline Water & 0.08 & $\mathrm{NA}^{*}$ & $\mathrm{NA}^{*}$ & $\mathrm{NA}^{*}$ & $\mathrm{NA}^{*}$ \\
Evergreen broadleaf forest & 0.14 & 100 & 6 & 3 & 22 \\
Deciduous broadleaf forest & 0.16 & 100 & 6 & 3 & 20 \\
Mixed forests & 0.16 & 125 & 2 & 10 & 22 \\
Closed shrub land & 0.22 & 100 & 5 & 3 & 22 \\
Open shrub lands & 0.22 & 100 & 1 & 3 & 22 \\
Woody savannahs & 0.15 & 100 & 6 & 2 & 17 \\
Savannahs & 0.18 & 100 & 4 & 2 & 22 \\
Grasslands & 0.22 & 50 & 2 & 1 & 15 \\
Permanent wetlands & 0.16 & 150 & 1 & 0 & 1 \\
Urban and built-up & 0.18 & 200 & 3 & 2 & 15 \\
Cropland-natural vegetation & 0.17 & 50 & 4 & 1 & 15 \\
Barren or sparsely vegetated & 0.27 & 1 & 1 & 0 & 22 \\
\hline
\end{tabular}

${ }^{*} \mathrm{NA}=$ Not Applicable.

\section{Water balance modelling in a semi-arid environment}

D. Deus et al.

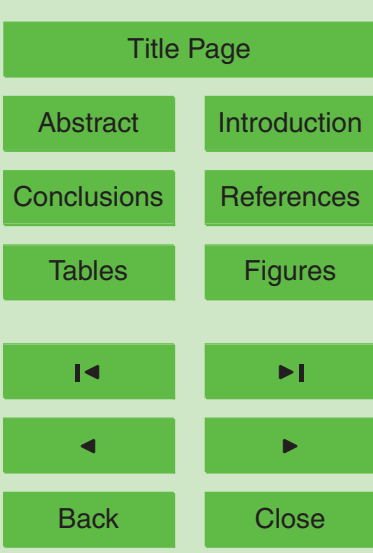

Full Screen / Esc

Printer-friendly Version

Interactive Discussion 


\section{HESSD}

8, 8737-8792, 2011

Table 2. Annual mean modelled water balance for the entire catchment (period 2001-2009). All units are in $\mathrm{mm} \mathrm{yr}^{-1}$ per year and for the lake water balance elements are estimated in $\mathrm{km}^{3} \mathrm{yr}^{-1}$.

\begin{tabular}{|c|c|c|c|c|}
\hline \multirow[b]{2}{*}{ Component } & \multicolumn{2}{|c|}{ Catchment basin } & \multicolumn{2}{|c|}{ Lake Manyara } \\
\hline & Inflow & Loss & Inflow & Loss \\
\hline Precipitation & $611.587(99.73 \%)$ & - & $0.216(47 \%)$ & - \\
\hline $\mathrm{ET} / \mathrm{E}$ & - & $664.234(98.13 \%)$ & - & $0.424(100 \%)$ \\
\hline Runoff & - & $12.731(2.07 \%)$ & - & - \\
\hline Inflow & - & - & $0.240(53 \%)$ & - \\
\hline Ground water & $1.675(0.27 \%)$ & - & - & - \\
\hline Total & 613.261419 & 676.9647 & 0.456 & 0.424 \\
\hline Water balance & \multicolumn{2}{|c|}{-63.703} & \multicolumn{2}{|c|}{0.032} \\
\hline
\end{tabular}

\section{Water balance modelling in a semi-arid environment}

D. Deus et al.

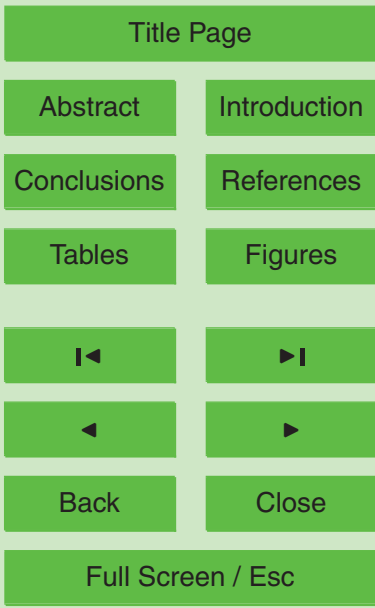

Printer-friendly Version

Interactive Discussion 


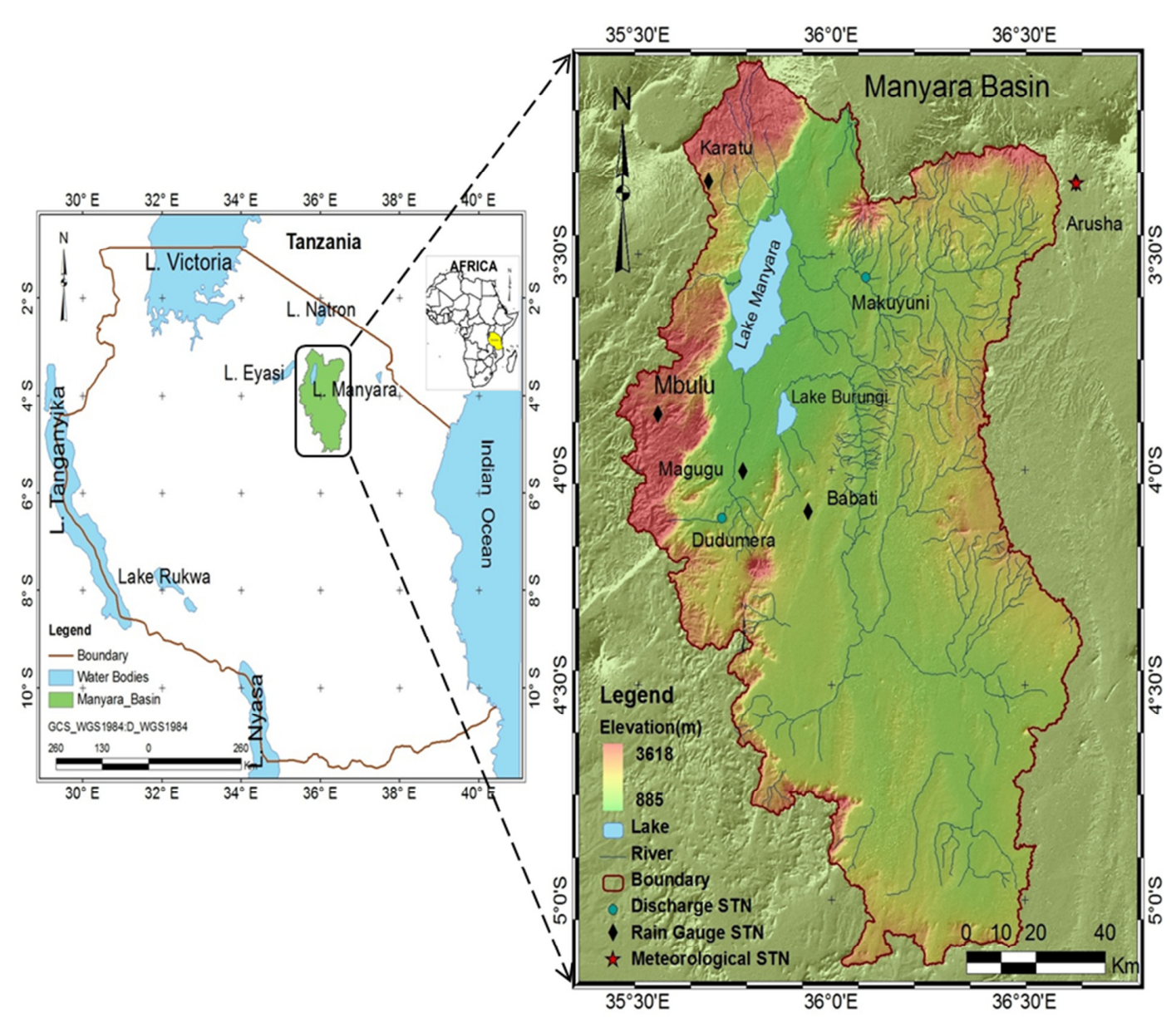

Fig. 1. Lake Manyara and its catchment basin in northern Tanzania.

\section{HESSD}

8, 8737-8792, 2011

\section{Water balance modelling in a semi-arid environment}

D. Deus et al.

\section{Title Page}

\section{Abstract}

Introduction

Conclusions

References

Tables

Figures

14

4

Back

Full Screen / Esc

Printer-friendly Version

Interactive Discussion 


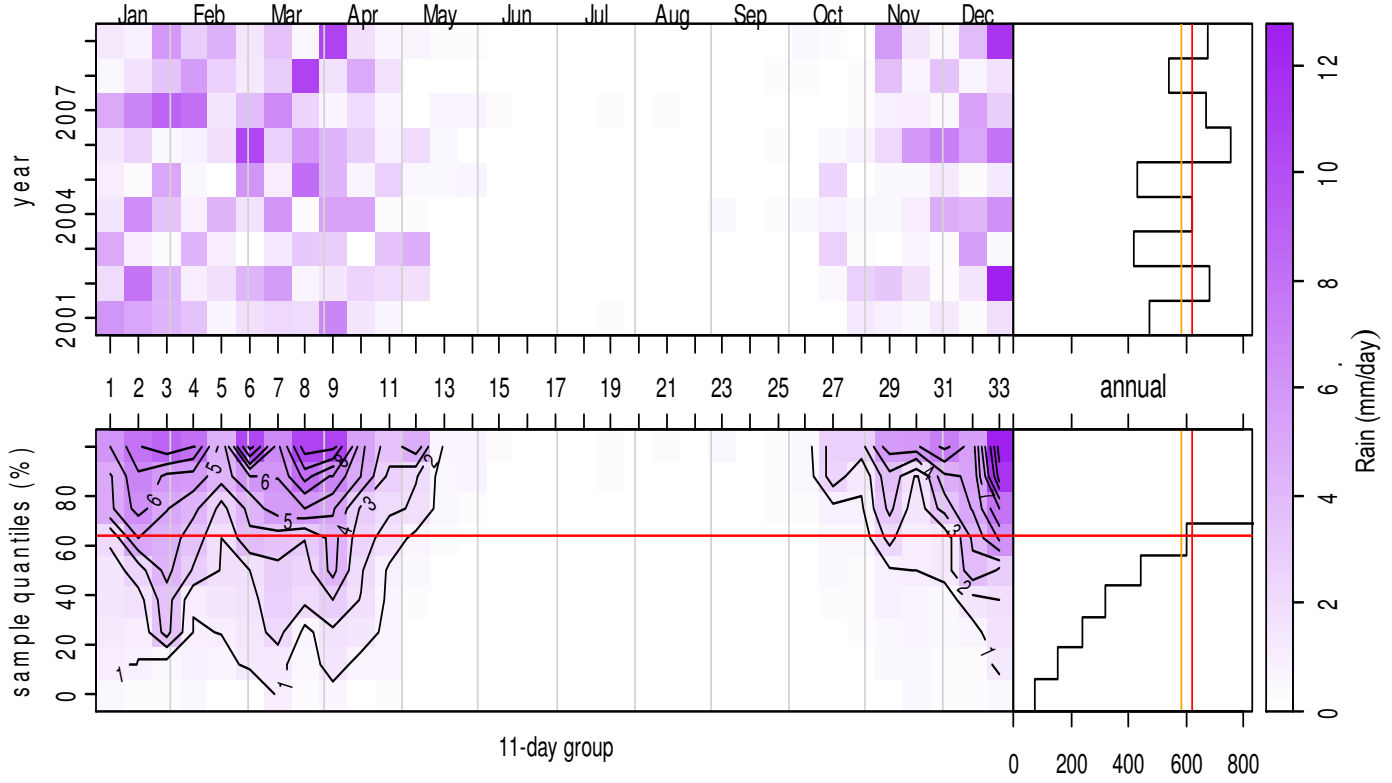

Fig. 2. Lake Manyara seasonal rainfall pattern 1 January 2001 and 31 December 2009; created based 11-day groups, starting in January. The upper-left frame is the normalized sum of daily precipitation rates for each case and annum pair, which sum row-wise to the upper-right frame to present annual precipitation totals; the lower-left frame is sorted vertically to represent the sample quantiles, and is contoured; the lower-right frame is the row-wise sum of sample quantiles; the vertical (red) line indicates the median of the annual sums, and the horizontal line represents the seasonal "normal" that has the same annual amount.
HESSD

8, 8737-8792, 2011

\section{Water balance modelling in a semi-arid environment}

D. Deus et al.

\section{Title Page}

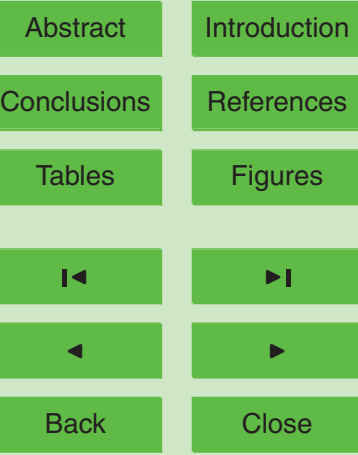

Full Screen / Esc

Printer-friendly Version

Interactive Discussion 


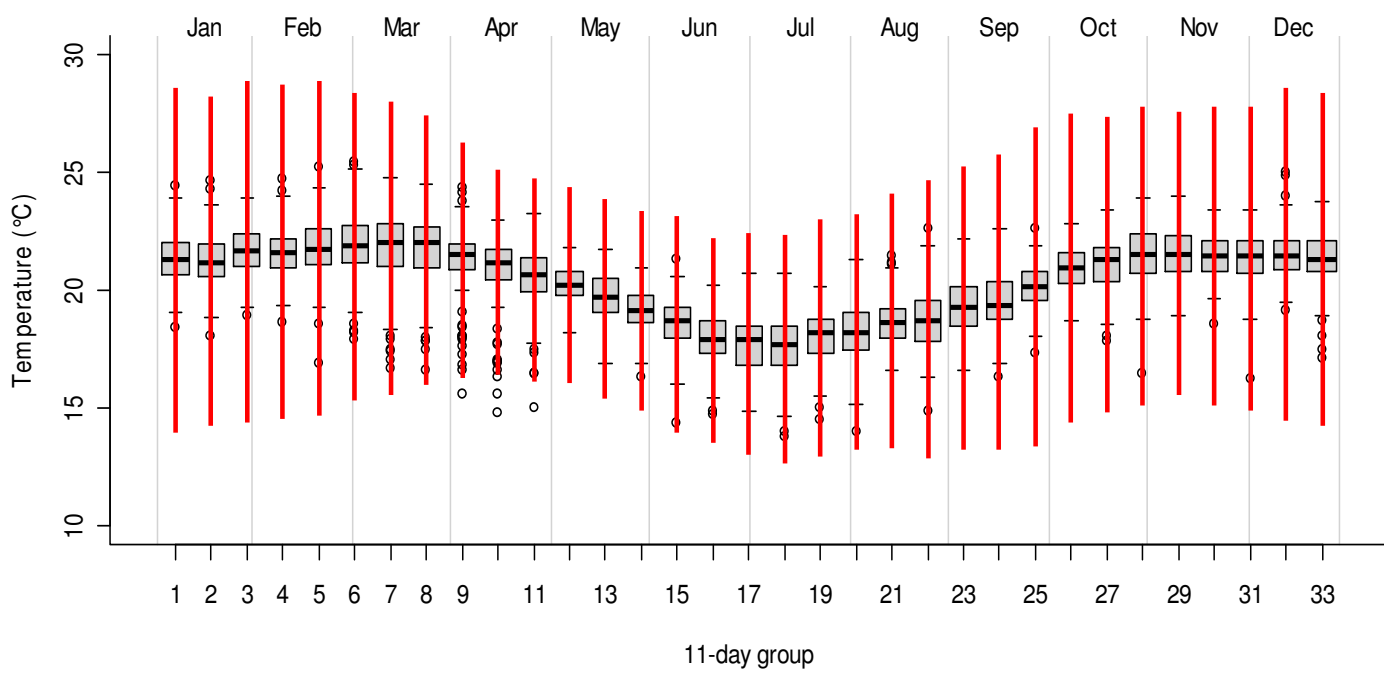

Fig. 3. Lake Manyara temperature normal 2001-2009. Boxplots are from daily mean values and thick vertical lines represent diurnal variability as derived from median daily maximum and minimum temperatures.

\section{HESSD}

8, 8737-8792, 2011

\section{Water balance modelling in a semi-arid environment}

D. Deus et al.

\section{Title Page}

\section{Abstract}

Introduction

Conclusions

References

Tables

Figures

14

4

Back

Close

\section{Full Screen / Esc}

Printer-friendly Version

Interactive Discussion 


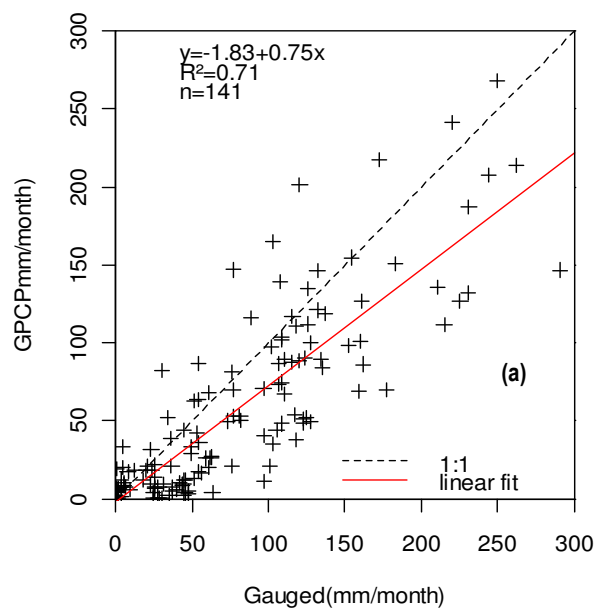

\section{HESSD}

8, 8737-8792, 2011

\section{Water balance modelling in a semi-arid environment}

D. Deus et al.

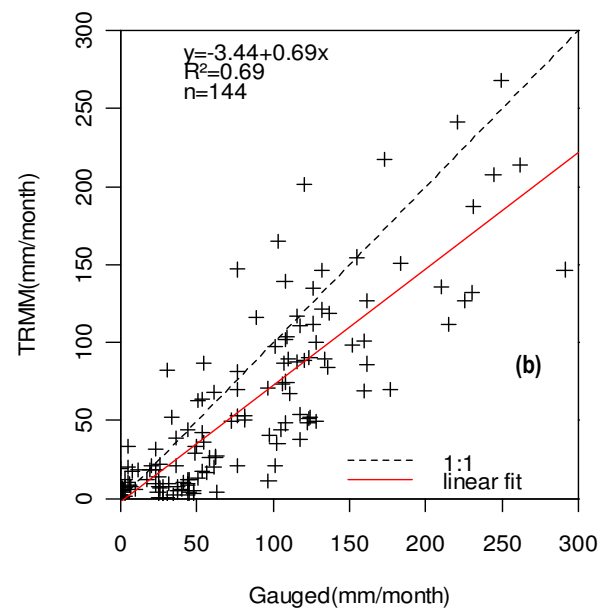

Title Page

Abstract

Introduction

Conclusions

References

Tables

Figures

14

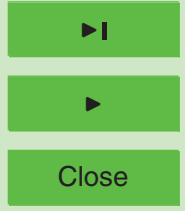

Back

Close

Full Screen / Esc

Printer-friendly Version

Fig. 4. (a) Comparison of GPCP precipitation and rain gauge data. (b) TRMM 3B43 V6 accumulated precipitation and rain gauge data. 

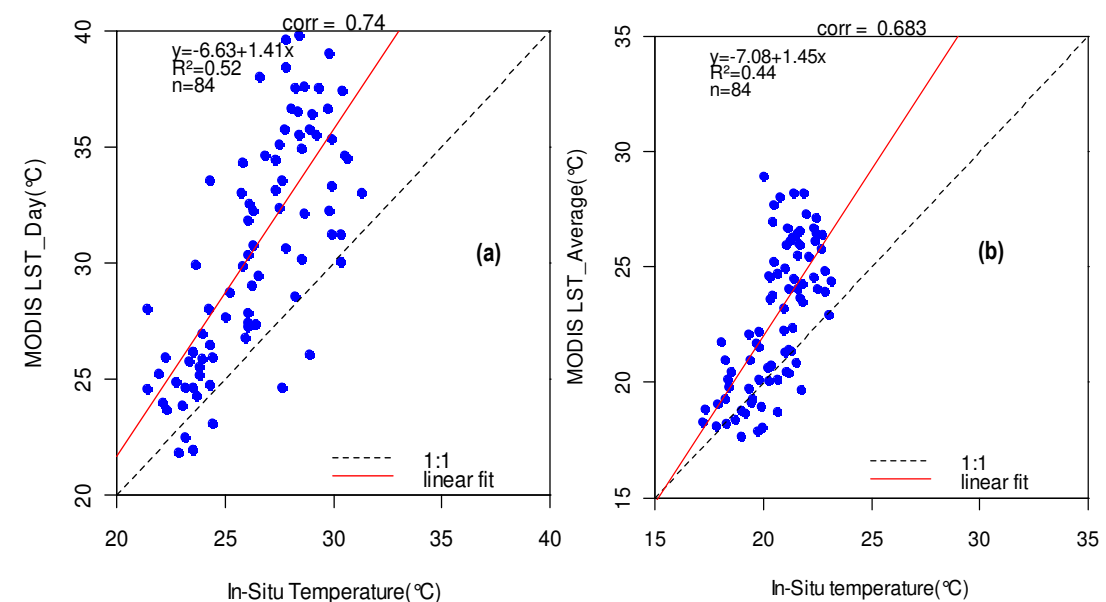

HESSD

8, 8737-8792, 2011

\section{Water balance modelling in a semi-arid environment}

D. Deus et al.

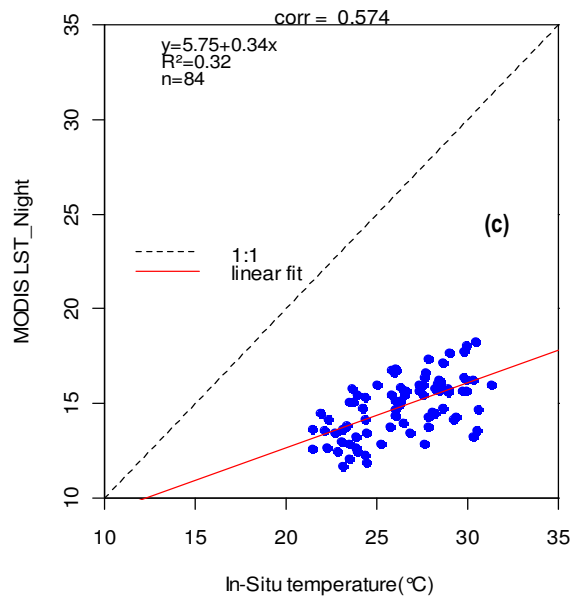

Fig. 5. Comparison of (a) monthly day time MODIS LST and in-situ temperature; (b) MODIS average monthly LST and in-situ temperature; (c) monthly night time MODIS LST and in- situ data.

Title Page

Abstract

Introduction

Conclusions

References

Tables

Figures

14

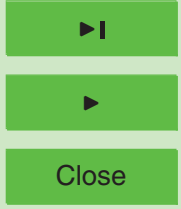

Back

Full Screen / Esc

Printer-friendly Version

Interactive Discussion 


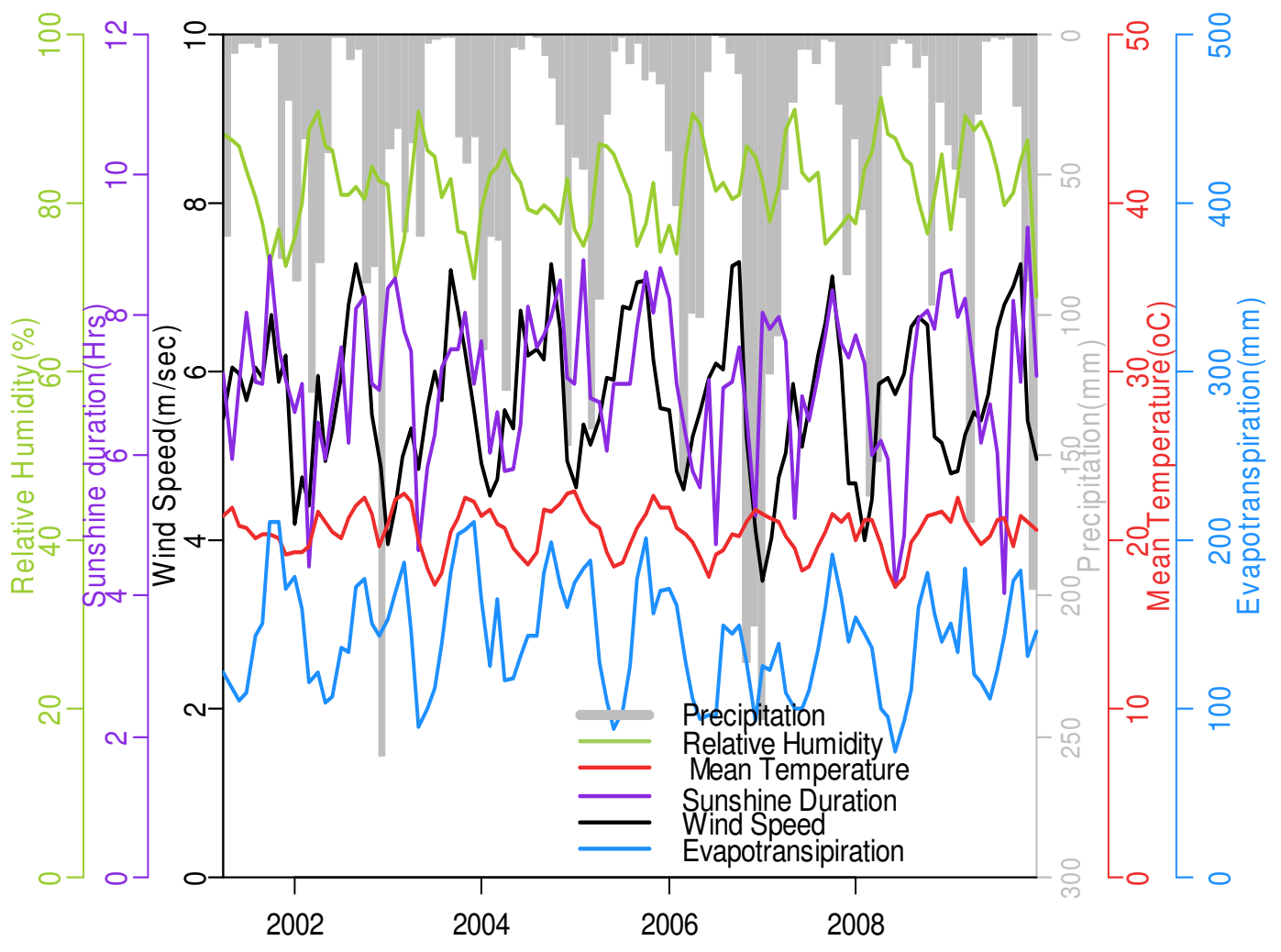

Fig. 6. Observed meteorological datasets in Manyara basin.

\section{HESSD}

8, 8737-8792, 2011

\section{Water balance modelling in a semi-arid environment}

D. Deus et al.

\section{Title Page}

Abstract

Introduction

Conclusions

References

Tables

Figures

14

4

Back

Close

Printer-friendly Version

Interactive Discussion 


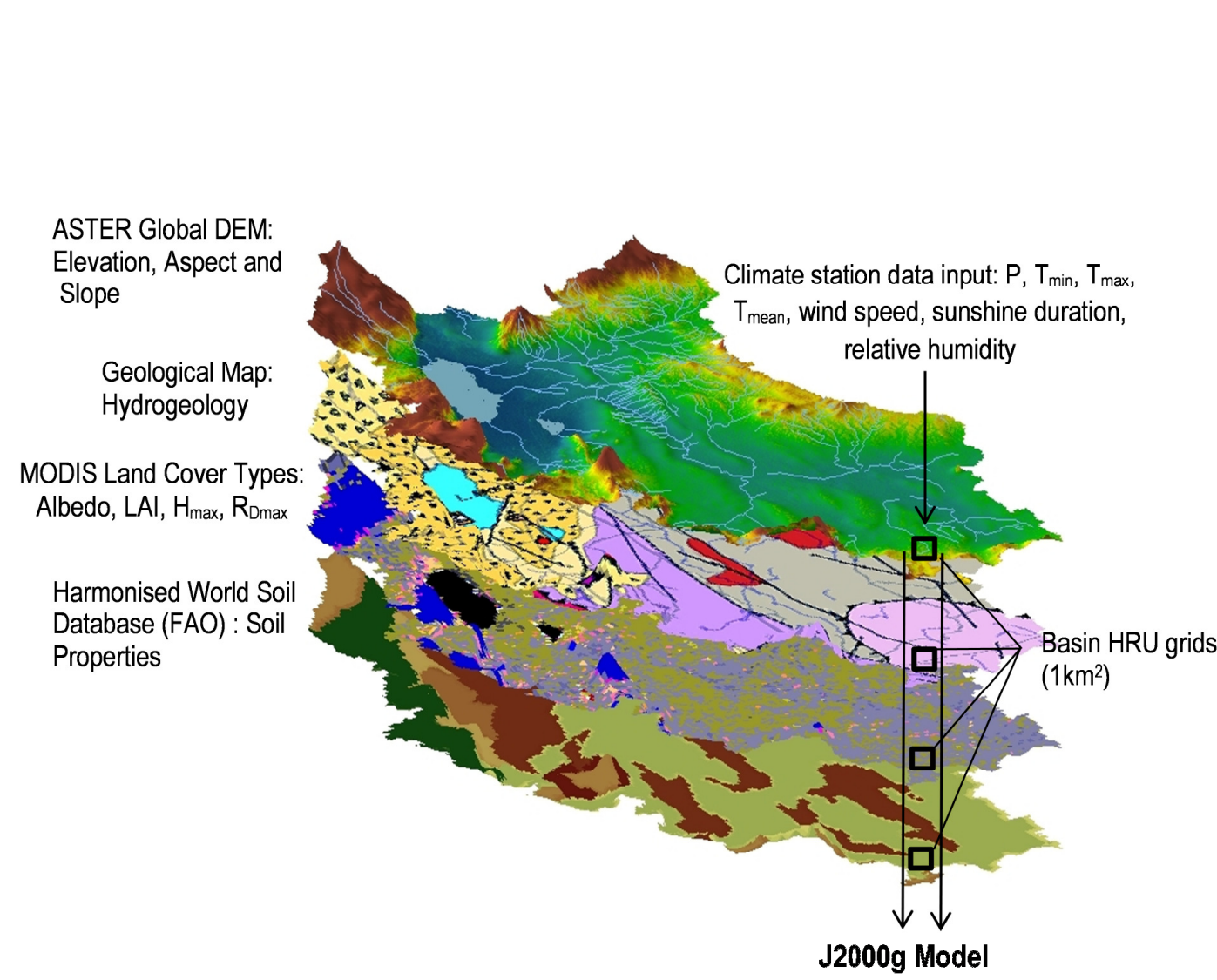

Fig. 7. J2000g model input climate data and spatial distributions of physical parameters.

\section{HESSD}

8, 8737-8792, 2011

\section{Water balance modelling in a semi-arid environment}

D. Deus et al.

\section{Title Page}

\section{Abstract}

Conclusions

Tables

14

4

Back

Full Screen / Esc
Printer-friendly Version 


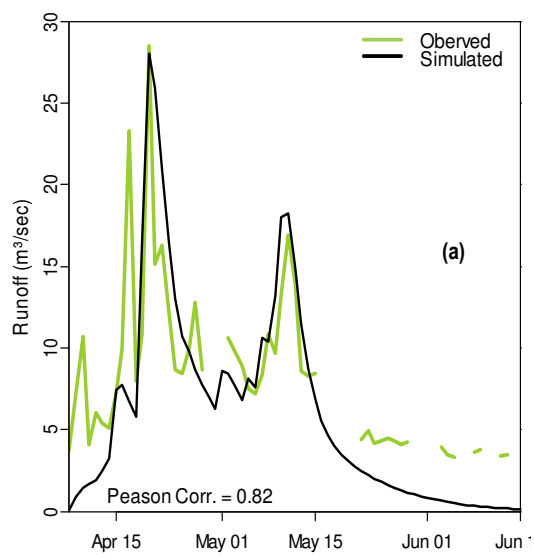

\section{HESSD}

8, 8737-8792, 2011

\section{Water balance modelling in a semi-arid environment}

D. Deus et al.

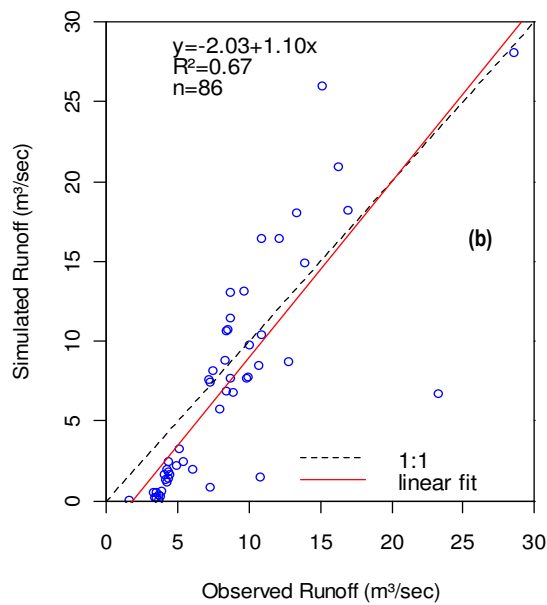

Title Page

Abstract Introduction

Conclusions

References

Tables

Figures

14

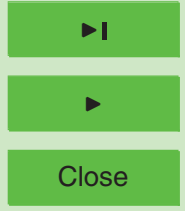

Back

Full Screen / Esc

Printer-friendly Version

Fig. 8. (a) Observed and simulated runoff for calibration period April-June 1980: $N S=0.60$, RMSE $=3.5$, PBias $=-2.9 \%, A V E=12.5$. (b) Relationship between observed and simulated runoff as depicted using linear regression. 


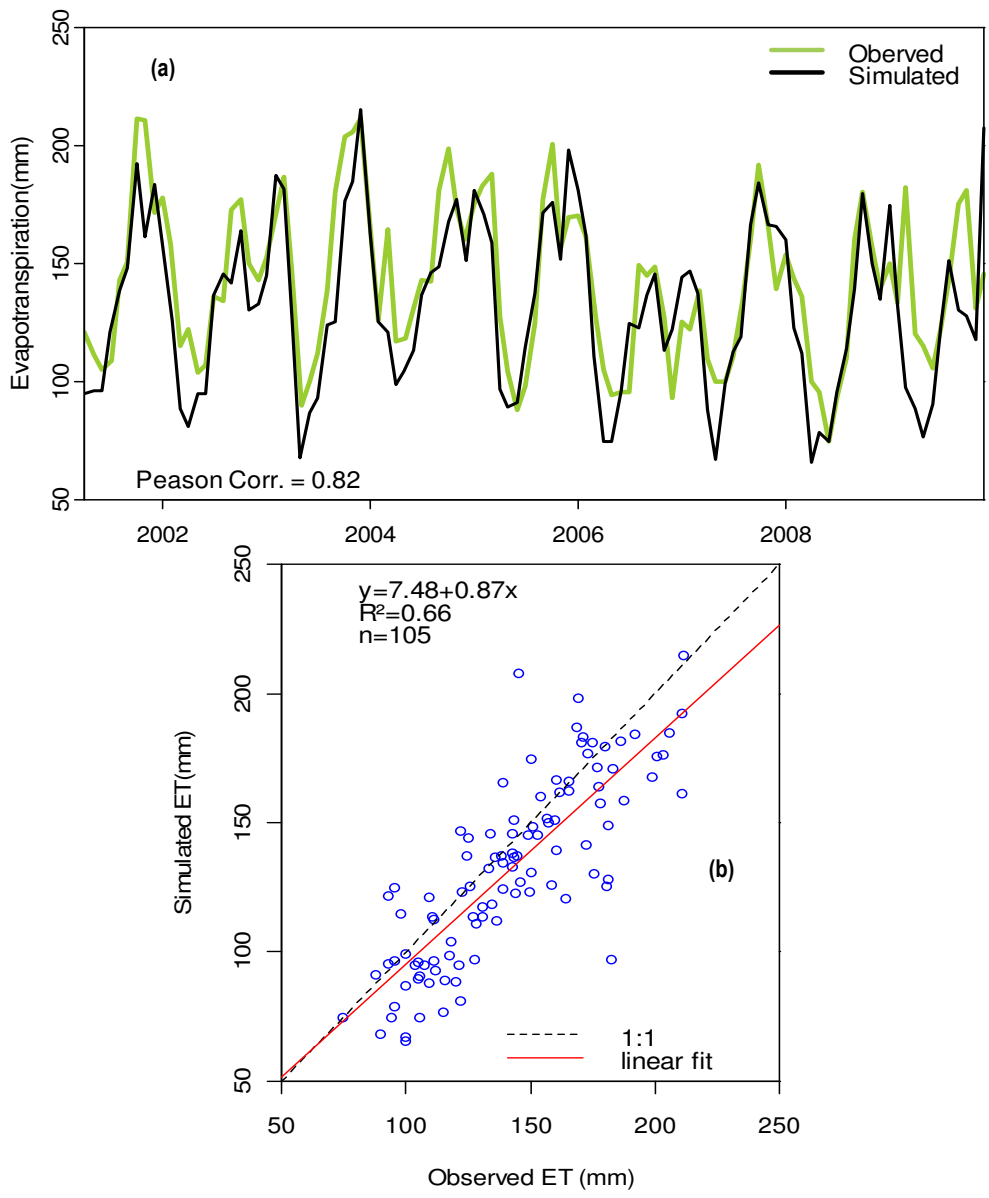

HESSD

8, 8737-8792, 2011

\section{Water balance modelling in a semi-arid environment}

D. Deus et al.

Title Page

Abstract

Introduction

Conclusions

References

Tables

Figures

14

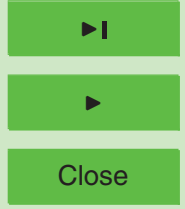

Back

Full Screen / Esc

Printer-friendly Version

Fig. 9. (a) Relationship between simulated and observed Evapotranspiration for validation period (2001-2009). (b) Scatter plot displaying a coefficient of determination, $R^{2}=0.66$. 


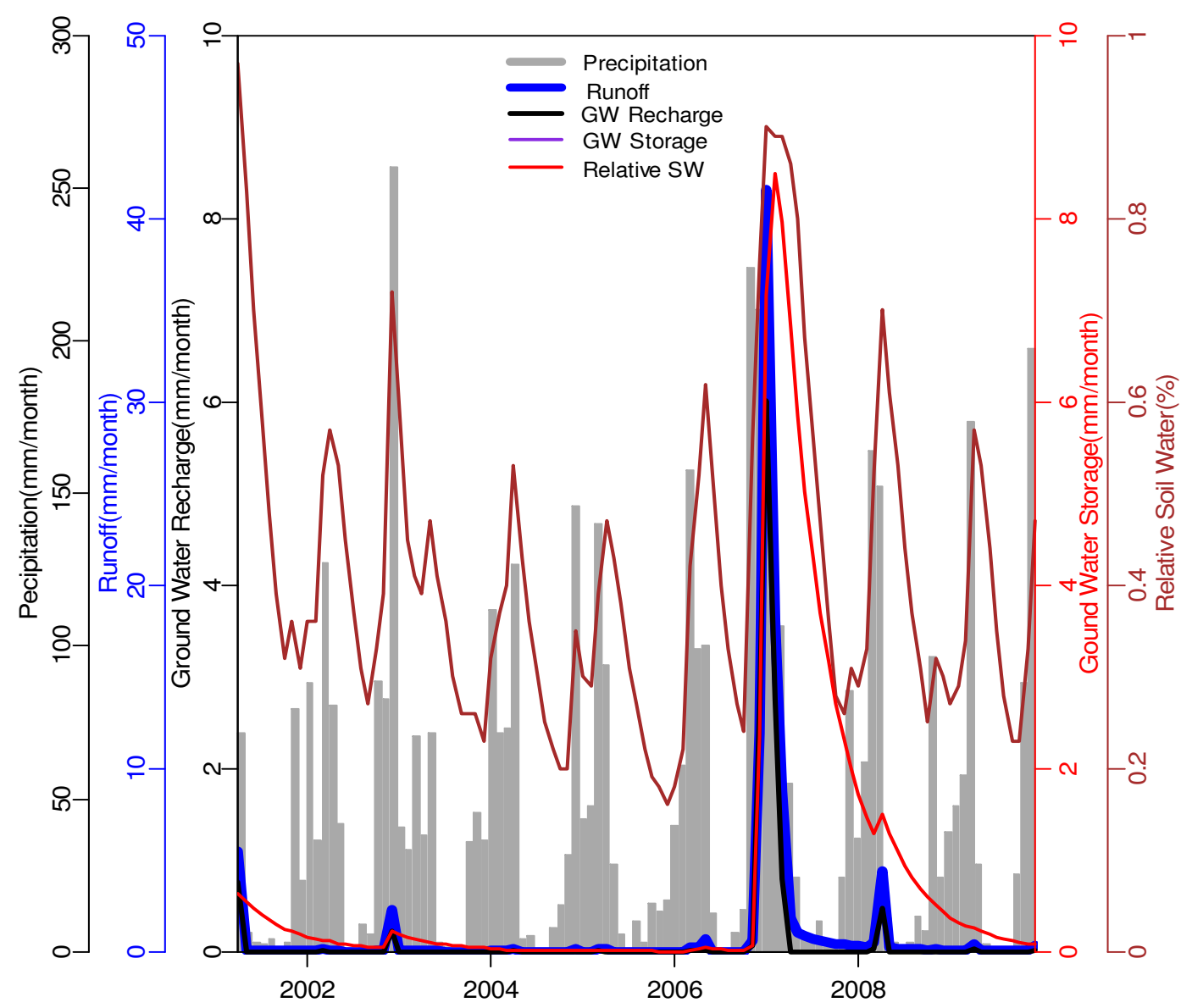

Fig. 10. Monthly variation of the components of water balance in Lake Manyara basin during the study period 2001-2009.

\section{HESSD}

8, 8737-8792, 2011

\section{Water balance modelling in a semi-arid} environment

D. Deus et al.

Title Page

Abstract

Introduction

Conclusions

References

Tables

Figures

14

$\rightarrow$

4

Back

Close

\section{Full Screen / Esc}

Printer-friendly Version

Interactive Discussion 


\section{HESSD}

8, 8737-8792, 2011

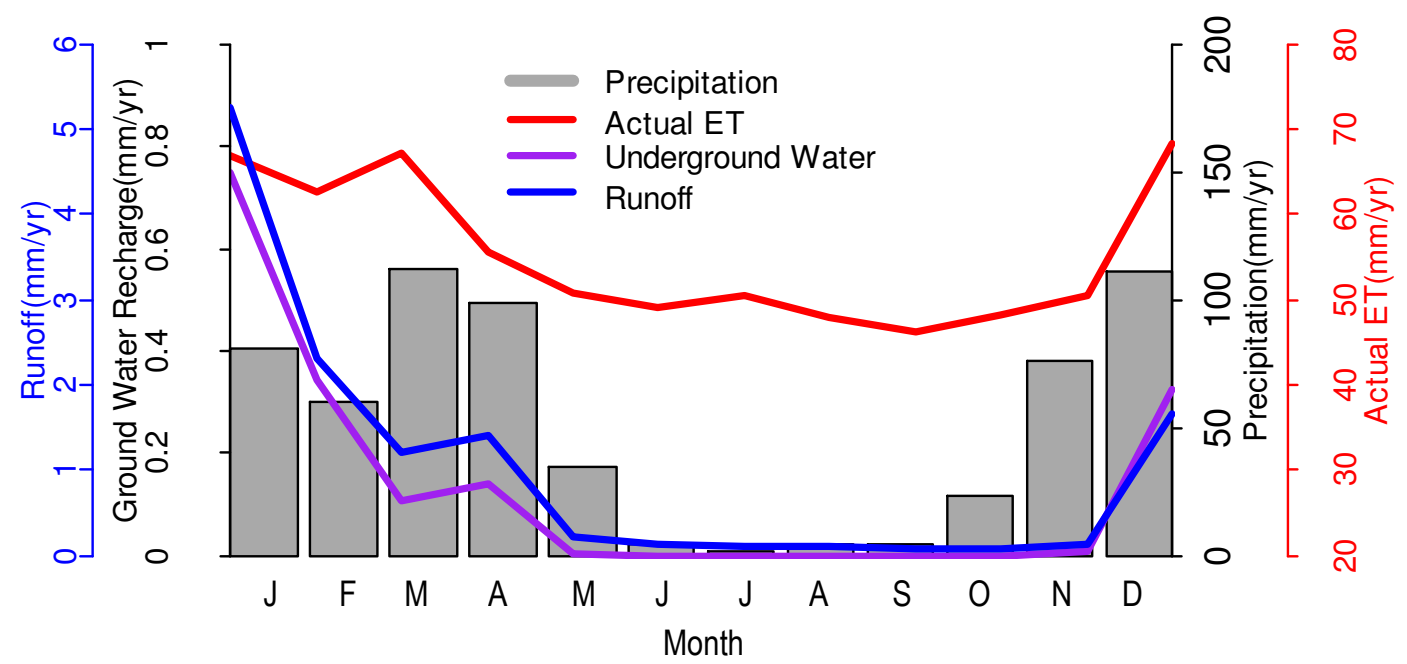

Fig. 11. Mean monthly annual water balance parameter variation for Lake Manyara catchment (2001-2009).

\section{Water balance modelling in a semi-arid environment}

D. Deus et al.

\section{Title Page}

\section{Abstract}

Introduction

Conclusions

References

Tables

Figures

14

Back

Close

\section{Full Screen / Esc}

Printer-friendly Version

Interactive Discussion 


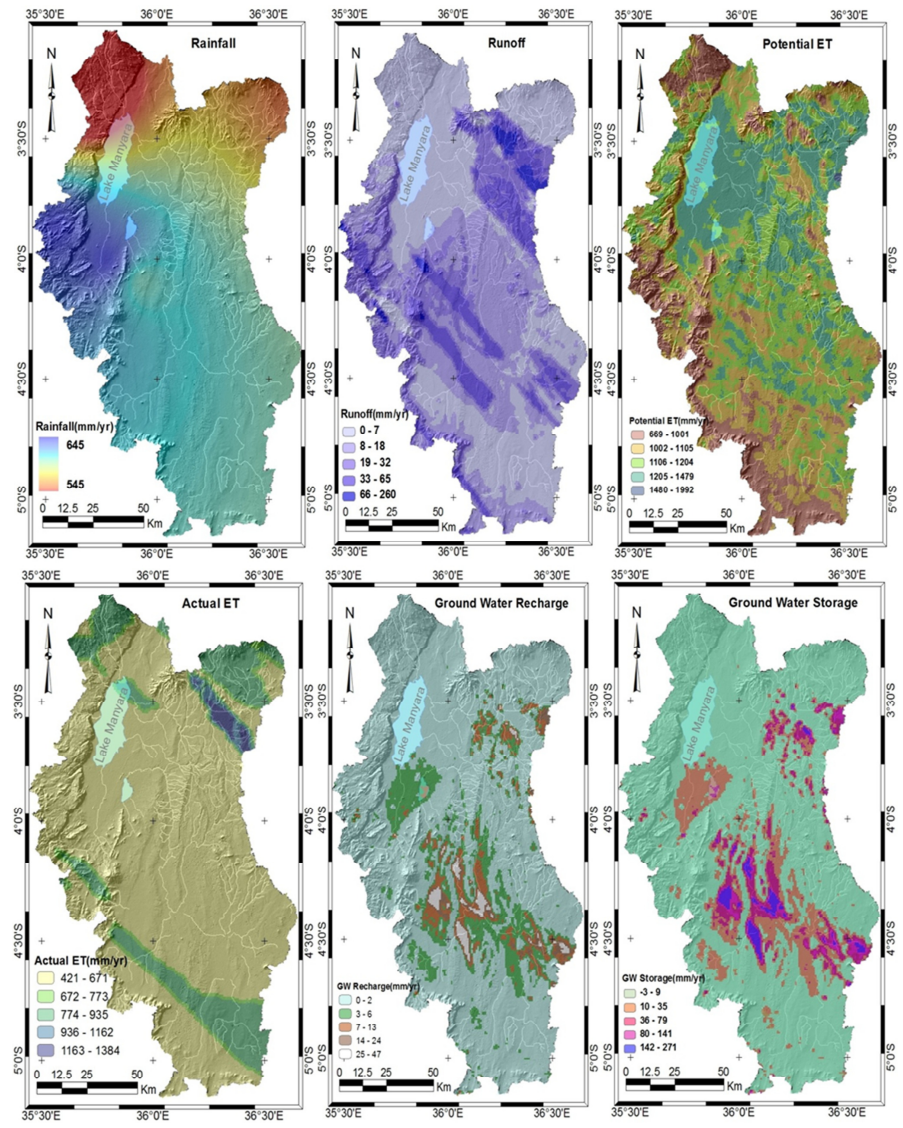

Fig. 12. Spatial distributed annual water balance parameters over the study period (20012009). On top, the spatial distributions are: Precipitation, runoff and potential evapotranspiration. Bottom: actual evapotranspiration, ground water recharge and storage. All units are in $\mathrm{mm}$ per month.

\section{HESSD}

8, 8737-8792, 2011

\section{Water balance modelling in a semi-arid environment}

D. Deus et al.

\section{Title Page}

\section{Abstract}

Conclusions

Tables

14

$\triangleleft$

\section{Back}

\section{Full Screen / Esc}

Printer-friendly Version 


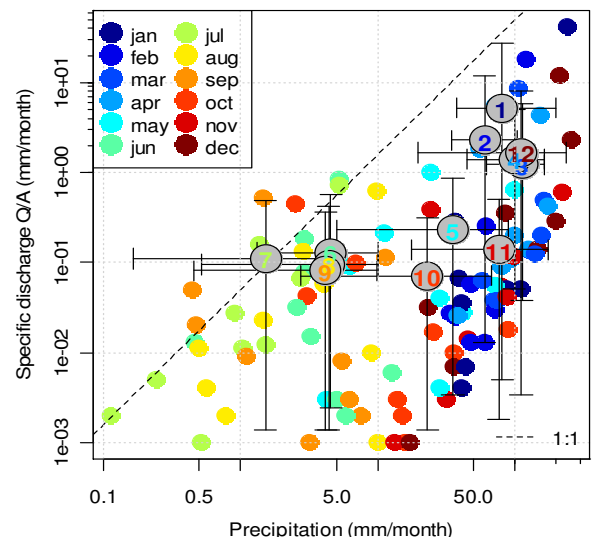

\section{HESSD}

8, 8737-8792, 2011

\section{Water balance modelling in a semi-arid environment}

D. Deus et al.

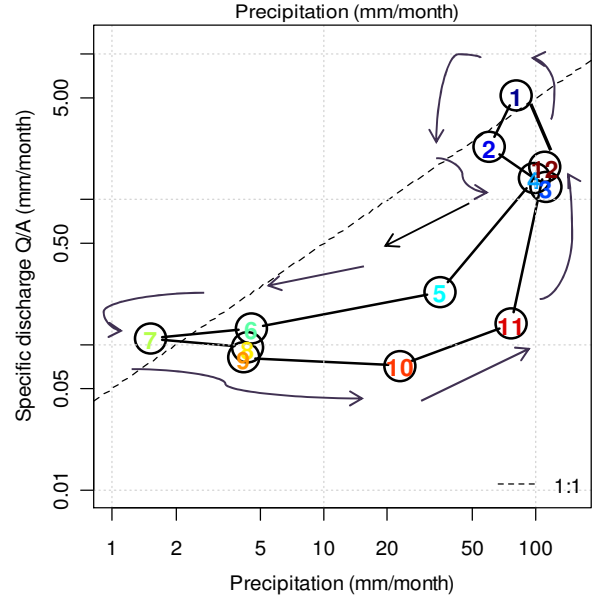

Title Page

Abstract Introduction

Conclusions References

Tables Figures

14 $>$ I

4

Back

Close

\section{Full Screen / Esc}

Fig. 13. Annual precipitation-discharge hysteresis. (a) Monthly precipitation-simulated runoff. Numbered centres represent monthly mean values for individual months over the study period. Bars represent $5 \%$ and $95 \%$ quantiles. The dashed line refers to the direct relationship of precipitation and resulting discharge. (b) A mean yearly precipitation-simulated runoff hysteresis loop. Arrows indicate direction of rotation.

Printer-friendly Version

Interactive Discussion 

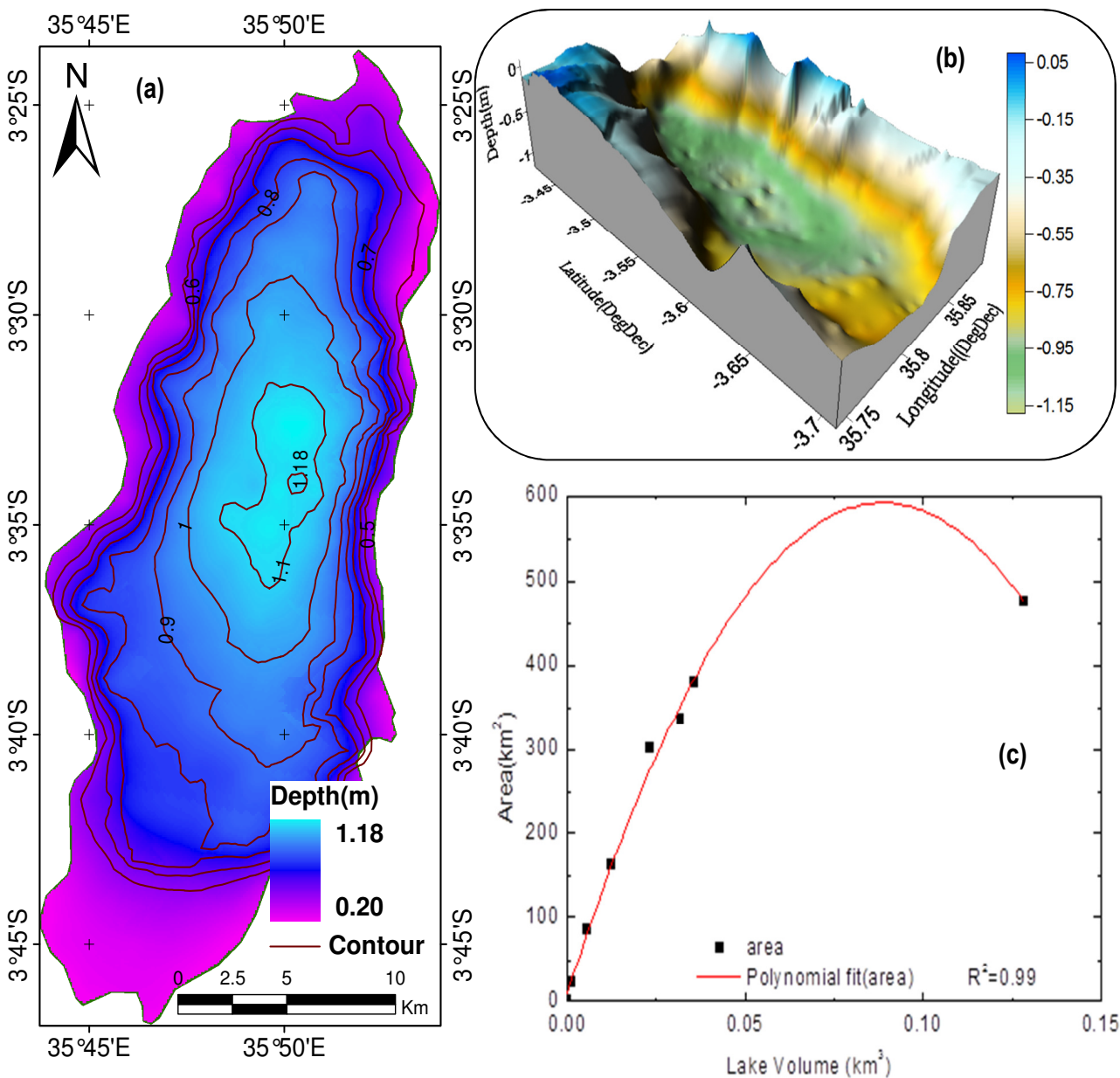

Fig. 14. (a) Bathymetric map, (b) Lake Morphology, (c) relative volume vs. relative area of the lake.

\section{HESSD}

8, 8737-8792, 2011

\section{Water balance modelling in a semi-arid environment}

D. Deus et al.

\section{Title Page}

\section{Abstract}

Introduction

Conclusions

References

Tables

Figures

14

4

Back

Full Screen / Esc

Printer-friendly Version

Interactive Discussion 


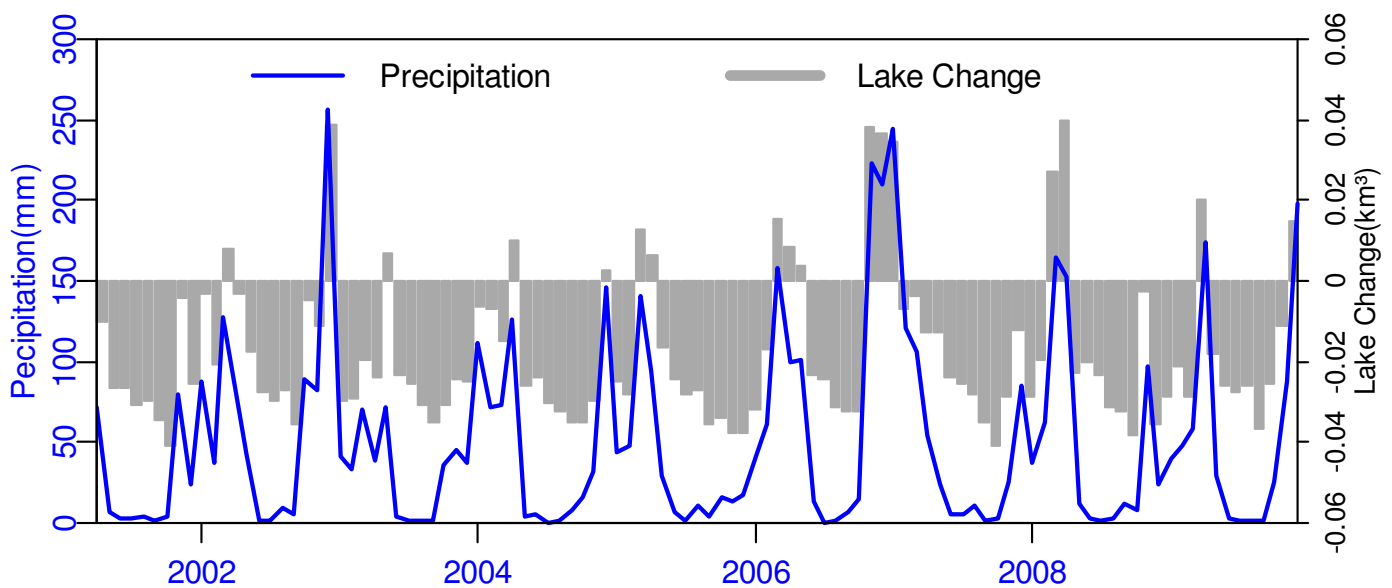

Fig. 15. Relation between Lake Manyara storage change and precipitation over the study period 2001-2009.

\section{HESSD}

8, 8737-8792, 2011

\section{Water balance modelling in a semi-arid environment}

D. Deus et al.

\section{Title Page}

\section{Abstract}

Introduction

Conclusions

References

Tables

Figures

14

$\rightarrow$

$\triangleleft$

Back

Close

\section{Full Screen / Esc}

Printer-friendly Version

Interactive Discussion 


\section{HESSD}

8, 8737-8792, 2011

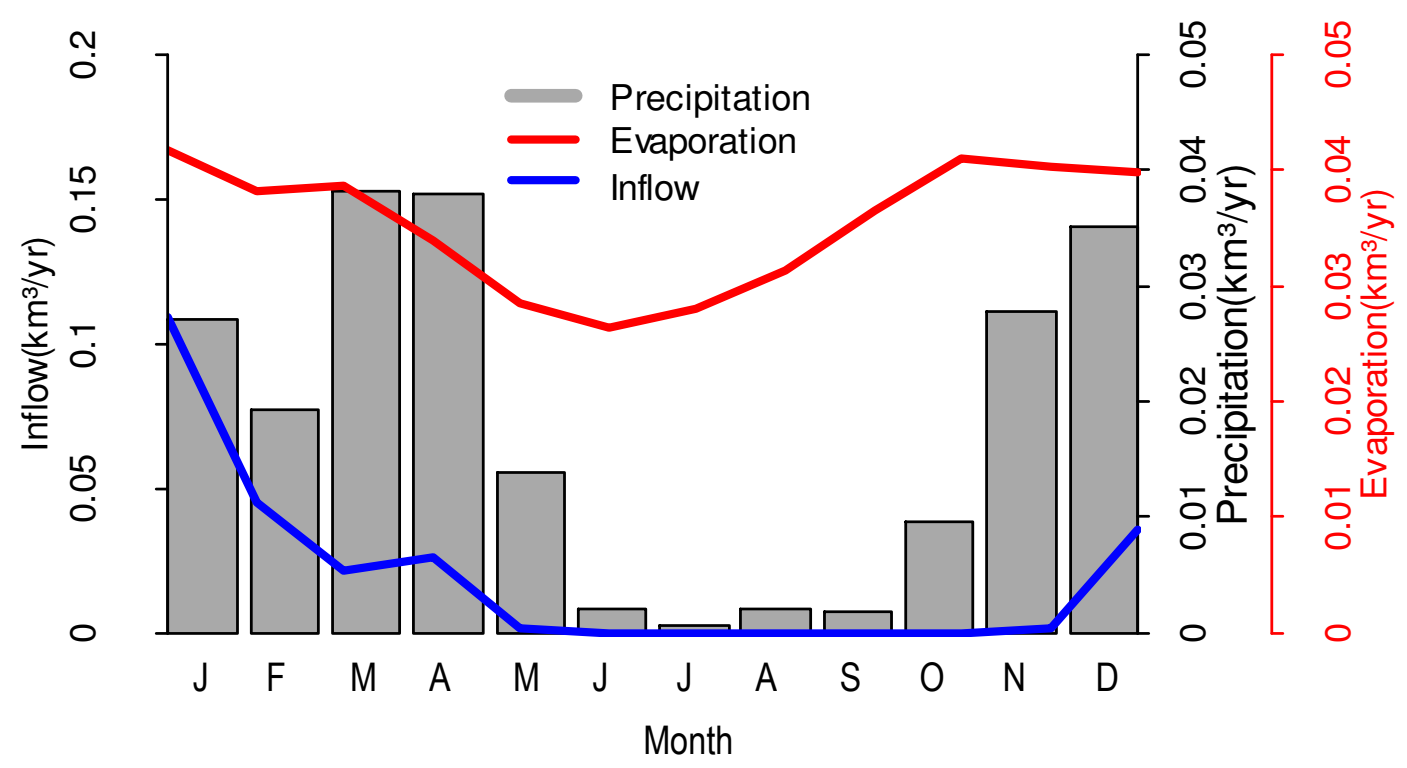

Fig. 16. Mean monthly yearly water balance parameter variation for Lake Manyara (20012009).

Water balance modelling in a semi-arid environment

D. Deus et al.

Title Page

Abstract

Introduction

Conclusions

References

Tables

Figures

14

DI

4

Back

Close

Full Screen / Esc

Printer-friendly Version

Interactive Discussion 


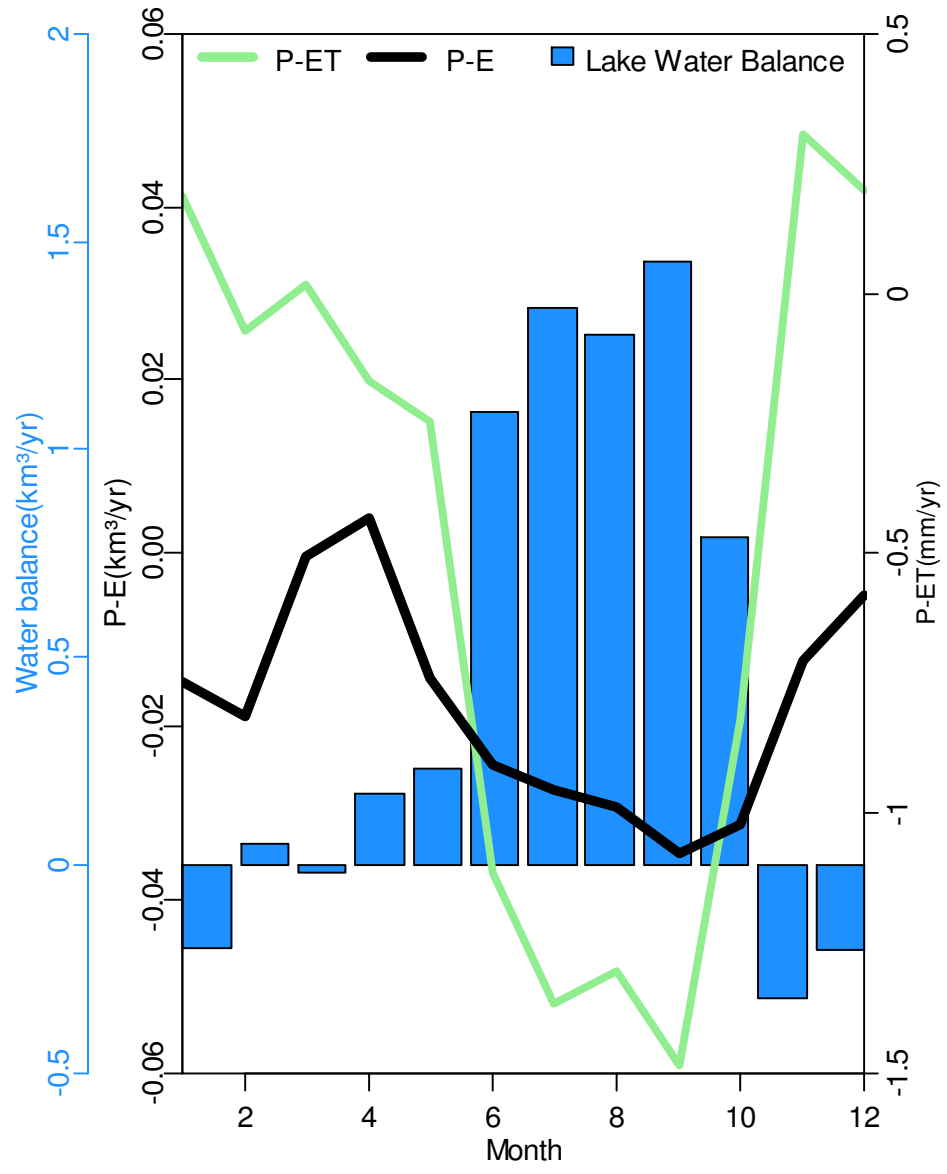

Fig. 17. Monthly means water balance parameter of Lake Manyara (2001-2009): precipitationEvapotranspiration $(P-\mathrm{ET})$, Precipitation-Evaporation $(P-E)$ and their weighted combination Lake Water balance.

\section{HESSD}

8, 8737-8792, 2011

\section{Water balance modelling in a semi-arid environment}

D. Deus et al.

\section{Title Page}

\section{Abstract}

Introduction

Conclusions

References

Tables

Figures

14

$\rightarrow 1$

4

Back

Close

\section{Full Screen / Esc}

Printer-friendly Version

Interactive Discussion 


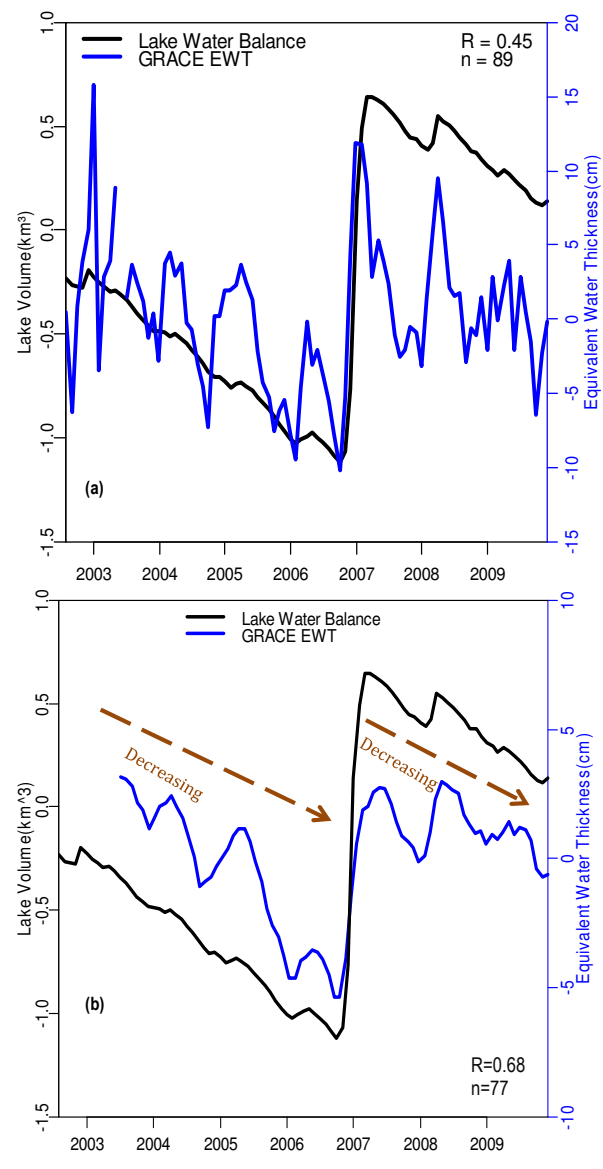

Fig. 18. (a) Lake water balance trend as compared to satellite gravimetry GRACE equivalent water thickness data. (b) Lake water balance and GRACE EWT; GRACE data are smoothed with a 12 month exponential moving average window.

\section{HESSD}

8, 8737-8792, 2011

\section{Water balance modelling in a semi-arid environment}

D. Deus et al.

Title Page

Abstract

Introduction

Conclusions

References

Tables

Figures

14

4

Back

Full Screen / Esc

Printer-friendly Version

Interactive Discussion 


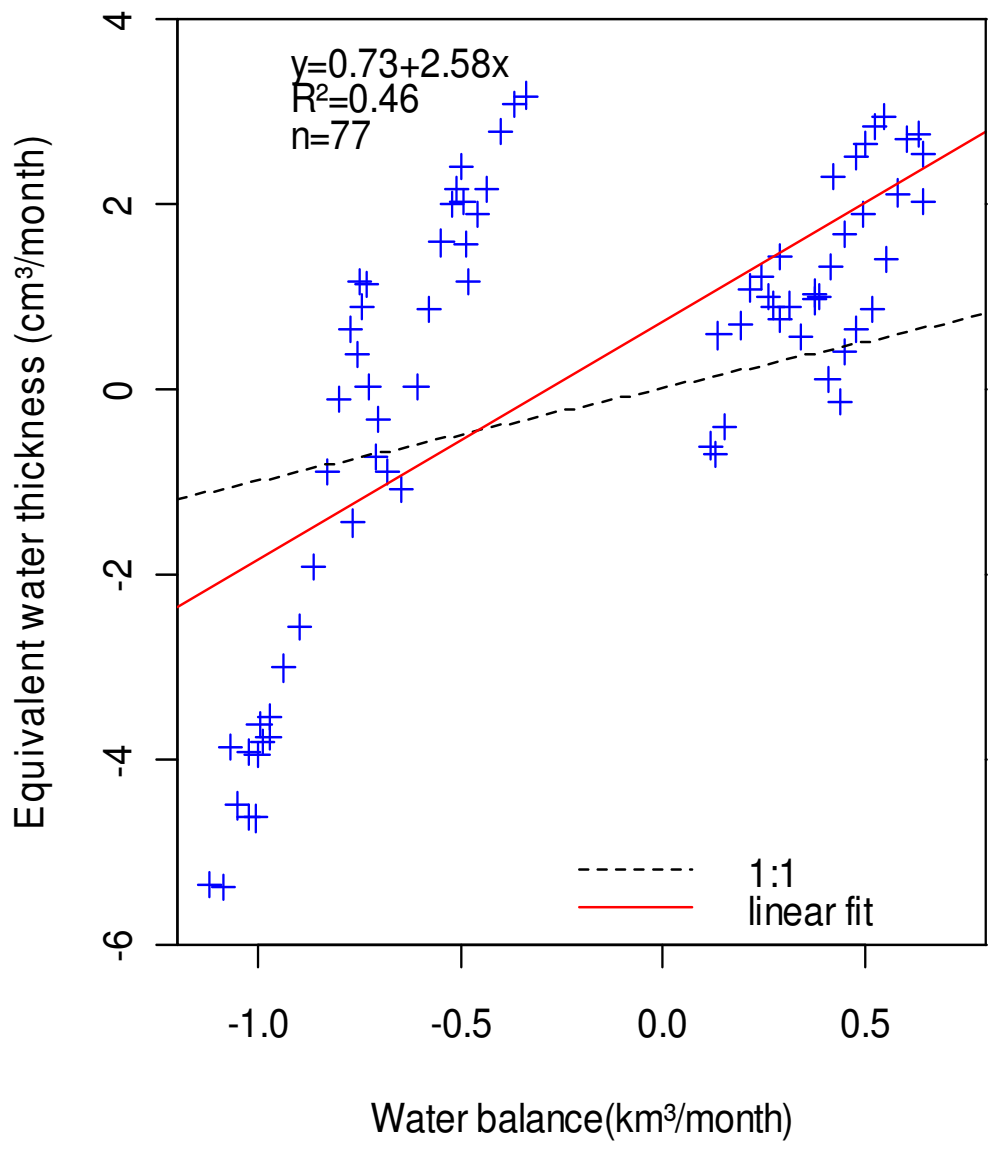

HESSD

8, 8737-8792, 2011

Water balance modelling in a semi-arid environment

D. Deus et al.

Title Page

Abstract

Introduction

Conclusions

References

Tables

Figures

14

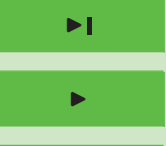

Back

Close

Full Screen / Esc

Printer-friendly Version

Fig. 19. Scatter plot of simulated lake wate balance nad GRACE EWT showing a coeffiecient of determination, $R^{2}=0.46$. Each point represent extracted mean monthly GRACE equivalent water thickness. 


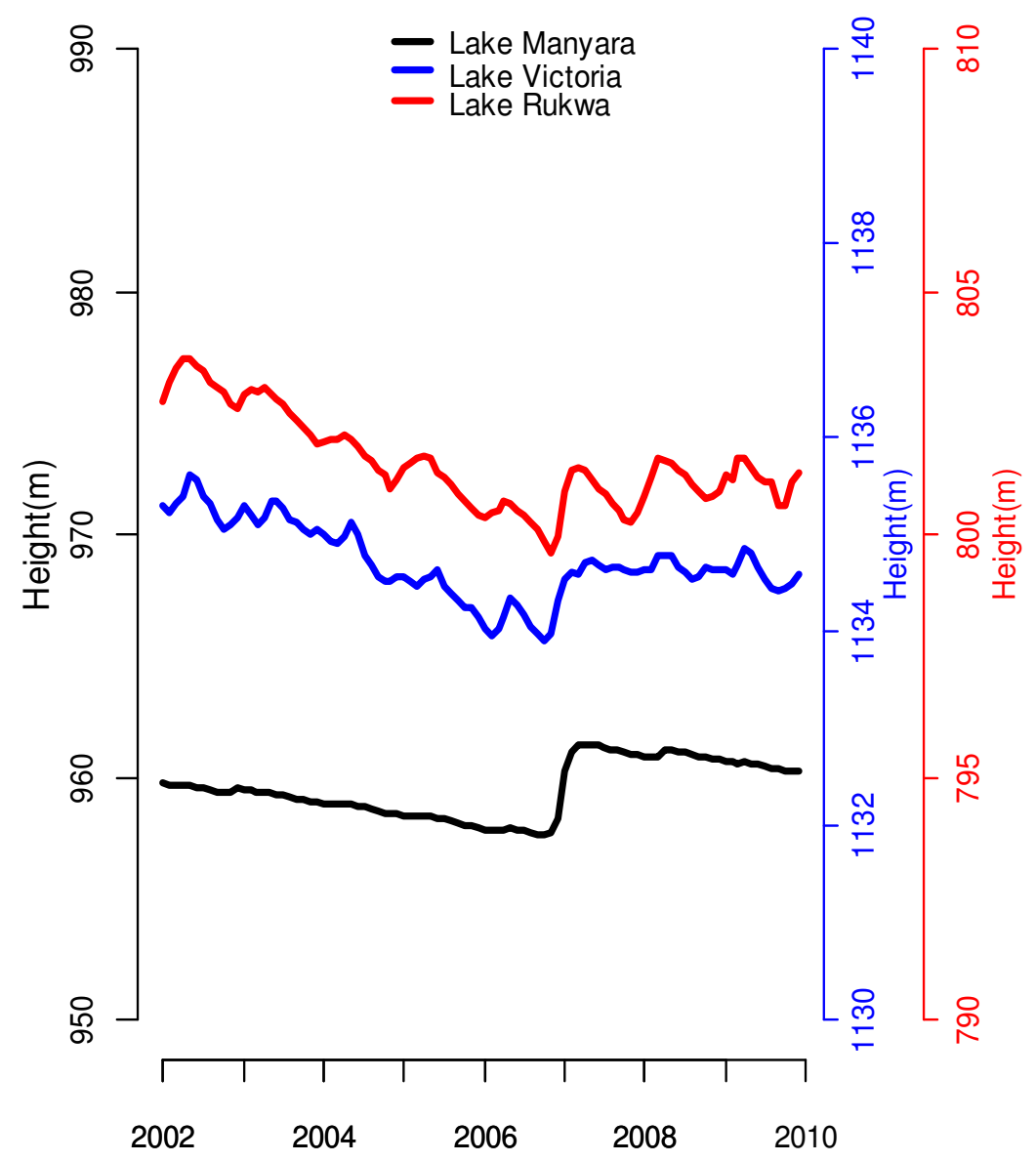

Fig. 20. Lake Manyara simulated water surface height variation as compared to neighbouring lakes in East African region. The data for Lake Victoria and Rukwa are based on Satellite altimetry measurement.

\section{HESSD}

8, 8737-8792, 2011

\section{Water balance modelling in a semi-arid environment}

D. Deus et al.

\section{Title Page}

\section{Abstract}

Conclusions

\section{Tables}

14

4

Back
Introduction

References

Figures

$>$ I

$>$

Close

\section{Full Screen / Esc}

Printer-friendly Version

Interactive Discussion 